http://dx.doi.org/10.1007/s11356-014-2540-5

(c) 2014, Springer-Verlag Berlin Heidelberg

The original publication is available at http://www.springerlink.com

\title{
Effects of increasing temperatures on biomarker responses and accumulation of hazardous substances in rope mussels (Mytilus galloprovincialis) from Bizerte lagoon
}

\author{
Naouel Kamel ${ }^{1,2, *}$, Thierry Burgeot ${ }^{2,{ }^{*}}$, Mohamed Banni $^{1}$, Mohamed Chalghaf $^{3}$, Simon Devin ${ }^{4}$, \\ Christophe Minier ${ }^{5}$, Hamadi Boussetta
}

\footnotetext{
${ }_{2}^{1}$ Biochemistry and Environmental Toxicology Research Unit, ISA Sousse University, Chott Mariem, Tunisia

2 Laboratory of Ecotoxicology, Biogeochemistry and Ecotoxicology Research Unit, BP 2105, 44311, Nantes, France

${ }^{3}$ Aquatic Environmental Exploitation Research Unit, ISPA Bizerte, BP 15, Rimel, Tunisia

${ }^{4}$ Interdisciplinary Laboratory of Continental Environments, University of Lorraine, Metz, France

${ }^{5}$ Laboratory of Ecotoxicology, University of le Havre, BP 540, 76058, Le Havre, France
}

\begin{abstract}
*: Corresponding authors : Naouel Kamel, email address : kamel naouel@yahoo.fr ; Thierry Burgeot, email address : tburgeot@ifremer.fr
\end{abstract}

\begin{abstract}
:
This study examined the influence of increasing temperatures in spring and summer on biochemical biomarkers in Mytilus galloprovincialis mussels sampled from Bizerte lagoon (northern Tunisia). Spatial and seasonal variations in a battery of seven biomarkers were analyzed in relation to environmental parameters (temperature, salinity, and $\mathrm{pH}$ ), physiological status (condition and gonad indexes), stress on stress (SoS), and chemical contaminant levels (heavy metals, polycyclic aromatic hydrocarbons (PAHs), and PCBs) in digestive glands. Integrated biological response (IBR) was calculated using seven biomarkers (acetylcholinesterase (AChE), benzo[a]pyrene hydroxylase (BPH), multixenobiotic resistance (MXR), glutathione S-transferase (GST), catalase (CAT), malondialdehyde (MDA), and metallothioneins (MT). Seasonal variations in biological response were determined during a critical period between spring and summer at two sites, where chemical contamination varies by a factor of 2 for heavy metals and a factor 2.5 for PAHs. The analysis of a battery of biomarkers was combined with the measurement of physiological parameters at both sites, in order to quantify a maximum range of metabolic regulation with a temperature increase of $11^{\circ} \mathrm{C}$ between May and August. According to our results, the MT, MDA, CAT, and AChE biomarkers showed the highest amplitude during the $11^{\circ} \mathrm{C}$ rise, while the $\mathrm{BPH}$, GST, and MXR biomarkers showed the lowest amplitude. Metabolic amplitude measured with the IBR at Menzel Abdelrahmen-the most severely contaminated station-revealed the highest metabolic stress in Bizerte lagoon in August, when temperatures were highest $29.1^{\circ} \mathrm{C}$. This high metabolic rate was quantified for each biomarker in the North African lagoon area and confirmed in August, when the highest IBR index values were obtained at the least contaminated site $2(\mathrm{IBR}=9.6)$ and the most contaminated site 1 (IBR = 19.6). The combined effects of chemical contamination and increased salinity and temperatures in summer
\end{abstract}


appear to induce a highest metabolic adaptation response and can therefore be used to determine thresholds of effectiveness and facilitate the interpretation of monitoring biomarkers. This approach, applied during substantial temperature increases at two sites with differing chemical contamination, is a first step toward determining an environmental assessment criteria (EAC) threshold in a North African lagoon.

Keywords: Biomarkers ; Mussels ; Lagoon biomonitoring ; Integrated biomarker response 


\section{Introduction}

In Mediterranean lagoon ecosystems, exchanges with the open sea and water circulation are mainly governed by winds and atmospheric pressure (Rougier et al. 2000). These systems are characterized by shallow waters (Armi et al. 2010), which allow the wind to mix the entire water column, thus enhancing diatom proliferation (Jarry et al. 1990). Bizerte lagoon, located in northern Tunisia, is linked to the Mediterranean Sea by a single entrance channel. It is situated near various industrial units and agricultural areas and has been used for shellfish farming since 1964 (Beji 2000). It is the recipient of a variety of industrial waste, pesticides and chemical fertilizers through soil erosion and runoffs, which has led to a decrease in bivalve and fish production (ANPE 1990). Indeed, direct and indirect discharges of urban and industrial wastes and runoffs have resulted in chemical contamination of the lagoon by various toxic compounds such as organochlorine pesticide OCPs (Cheikh et al. 2002), halogenated aromatics compounds such as PCBs (Derouiche et al. 2004), polycyclic aromatic hydrocarbons (PAHs) (Trabelsi and Driss 2005), polybrominated diphenyl ethers (PBDEs) and their methoxylated analogs (Ben Ameur et al. 2011) and heavy metals (Ben Garali et al. 2010).

Biomarkers are increasingly used to assess environmental quality and, in particular, the chemical quality of lagoons, in the aim of assessing the biological effects of environmental contaminants on aquatic organisms living in them (Ben Ameur et al. 2012). They are among the emerging tools used in monitoring programs to assess the biological effects of chemical contaminants (Allan et al. 2006; Depledge 2009) and can be used to reveal environmental stresses caused by contaminants and other environmental variables. The integration of biomarkers and chemical analysis is therefore an essential factor of success for establishing links between stress and pollution (Galloway et al. 2004a; Thain et al. 2008).

In poikilothermic organisms such as bivalves, ambient temperature is one of the major factors driving physiological and biochemical processes (Pfeifer et al. 2005). Mussels may be exposed to extreme temperature fluctuations and major changes in body temperature within a short period of time during the hot season (Sokolova 2004) and are capable of challenging sustained seasonal variations in environmental temperatures (Banni et al. 2011). In a previous study, we investigated oxidative stress and detoxification response in Mytilus galloprovincialis after exposure to thermal stress $\left(18-20-22-24-26^{\circ} \mathrm{C}\right)$ and a sublethal dose of benzo [a] pyrene (Kamel et al. 2012). Our results demonstrated the negative effects of acute heat stress on mussel response, manifested by cellular genotoxicity and cytotoxicity.

In order to study the in situ influence of elevated temperatures on mussels, we used rope mussels (M.galloprovincialis) as sentinel organisms to assess (i) variations in a suite of biomarkers, (ii) 
the capacity of mussels to accumulate hazardous substances and (iii) related effects of increasing summer temperatures in Bizerte lagoon. For this purpose, biomarkers of oxidative stress were measured in the gills and digestive glands of mussels in late spring and summer 2011. We particulary took the following criteria into consideration, in line with the results of large-scale biomonitoring programs such as MED POL and OSPAR (UNEP-RAMOGE. 1999; ICES 2010): survival in air (SoS), condition index, gonadic condition index, neutral red retention, benzo [a]pyrene hydroxylase (BPH) activity, glutathione S-transferase (GST) activity, catalase (CAT) activity, acetylcholinesterase (AChE) activity, multixenobiotic resistance (MXR), metallothioneins (MT) and lipid peroxidation.

Survival time in air can indicate the general health of organisms (Viarengo et al. 2007). Mussel survival time can be considered as a "Stress on Stress" (SoS) response. Similarly, the Condition Index (CI) can provide general information on the more general energy budget allocation of mussels (Gomiero et al. 2011). The CI summarizes the physiological activity of organisms (growth, reproduction, secretion, etc.) in given environmental conditions (Lucas and Beninger, 1985) and is mainly used for two purposes: first, to guarantee the quality of meat for the marketplace (Orban et al. 2002) and second, as an ecophysiological measurement of animal health status.

Activity of the biotransformation enzyme benzo[a]pyrene hydroxylase (BPH) can be used indirectly to measure CYP450 1A activity, which is involved in the biotransformation of xenobiotics (Snyder 2000). This biotransformation enzyme has previously been used as a biomarker of exposure to organic pollutants and, in particular, PAHs (Akcha et al. 2000; Burgeot et al. 2006; Banni et al. 2010). Glutathion S-transferase (GST) is involved in Phase II of biotransformation and thus in the detoxification of numerous environmental chemicals, as it catalyzes the conjugation of glutathione to electrophilic compounds (e.g. epoxides of PAHs), hence rendering them less reactive and more water-soluble (Cheung et al. 2001; Pan et al. 2009). P-glycoprotein (P-gp), multidrug resistance (MDR), two ATP-driven membrane pumps and the lung resistance protein (LRP), which is the main vault protein (MVP), are part of the Phase III system and involved in the excretion of conjugated metabolites. MXR is an MDR-like system that has been identified in marine invertebrates (McFadzen et al. 2000; Smital et al. 2000). The relevance of MXR has been demonstrated through its potential ability to protect aquatic organisms from DNA damage (Waldmann et al. 1995). MXR protein expression is inducible by exposure to toxic compounds (Minier and Moore. 1996). Quantities of these proteins vary significantly across differentially polluted sites (Minier et al. 2000). 
135 Catalase (CAT) is an antioxidant enzyme used as a biomarker of the oxidative stresses induced $\frac{1}{2} 6$ by a wide range of contaminants, including organic xenobiotics, heavy metals and PAHs (Livingstone 2001; Sureda et al. 2011). Malondialdehyde (MDA) is used as marker of membrane phospholipid oxidation through lipid peroxidation. Increased MDA levels in organisms may be related to the degradation of an environmental site due to decreased water quality (Charissou et al. 2004). Studies carried out on marine species have shown lipid peroxidation to be a relevant index of toxin-induced chemical injury (Avery et al. 1996).

Acetylcholinesterase (AChE) is an enzymatic biomarker of neurotoxicity and responsible for acetylcholine degradation. AChE activity is inhibited by the presence of pesticides such as organophosphorous compounds, carbamates and various heavy metals or PAHs in mussels (Bocquené et al., 1993; Mora et al. 1999). Tissue levels of metallothionein proteins (MT) were estimated in mussel digestive glands in order to evaluate their biological effects on sentinel organisms and assess trace metal pollution in the aquatic environment. MTs are involved in both homeostasis and detoxification (Viarengo and Nott 1993) and their accumulation is more obvious in gills, digestive glands and kidneys, hence reflecting the significant role of these tissues in the uptake, storage and excretion of metals (Bebianno and Langston. 1992).

Biomarker evaluation in mussels is a major tool used in aquatic environment biomonitoring to assess the causal relationship between exposure to environmental pollutants and long-term effects on individuals and populations (Bolognesi et al. 2004; Bodin et al. 2004). However, the exploration of large datasets of chemical and biological measurements requires a coherent suite of assessment criteria and tool indexes in order to provide standardized interpretations for monitoring purposes. In this aim, we attempted to determine assessment criteria for measuring biological effects by applying the OSPAR Strategy; we also applied the integrated biomarker response index (IBR) in order to interpret a global response from the various measured biomarkers. Background assessment criteria (BAC) and environmental assessment criteria (EAC) have already been developed for mussels and fish in the framework of the integrated marine environmental monitoring of chemicals and their effects in the Northeast Atlantic (Davies and Vethaak. 2012). The IBR index was computed using the biomarker measured in Mytilus galloprovincialis in order to assess ecological risks associated with pollution at Bizerte lagoon study sites.

The aim of this study was to examine the influence of increasing temperatures in spring and summer on the biomarker responses of mussels inhabiting a North African lagoon, recognized as a sensitive area in terms of temperature changes and pollution. Biomarker variations were initially compared during the highest temperature elevation, between spring and summer. The 
amplitude response of the biomarkers was then studied across two sites characterized by different levels of chemical contamination.

\section{Materials and Methods}

Study area

This study was performed at two sites in Bizerte lagoon (Fig.1). The Menzel Abdelrahmen site (S1) $\left(37^{\circ} 13^{\prime} \mathrm{N}, 9^{\circ} 51^{\prime} \mathrm{E}\right)$, located between the port and the former wastewater (ONAS) discharge, is characterized by urban effluents (Mahmoud et al. 2010), while the Baie des Carrières site (S2) $\left(37^{\circ} 13^{\prime} \mathrm{N}, 9^{\circ} 49^{\prime} \mathrm{E}\right)$, located in the channel between the lagoon and Mediterranean Sea, is subjected to intensive maritime traffic and various impacts from the channel area characterized by a strong hydrological dynamics (Khessiba et al. 2001; Cheikh et al. 2002).

Sampling strategy

Mussels of similar sizes (5-7 cm shell length) were sampled monthly from both sites in late spring and summer 2011. The same cohort of juvenile mussels from the same native area (Bizerte lagoon) was selected for this study. Two sites with contrasting levels of chemical contamination, S1 Menzel Abdelrahmen and S2 Baie des Carrières, were selected in the lagoon. These sites, which respectively show high and low chemical contamination levels, are suitable for comparison thanks to their homogeneous physicochemical parameters within the lagoon area.

The mussels were immediately transported to the laboratory. In the laboratory, two samples of 30 individuals were used for biometric analyses (shell length and soft body wet weight) and for the stress on stress test. 50-60 mussels were then scarified for excision of the digestive gland (DG) and gills (G), for the purpose of chemical and biomarker analyses. The sampled tissues were stored in liquid nitrogen at $-80^{\circ} \mathrm{C}$ prior to the assays. All biomarkers were analyzed in the same mussel, whereas stress on stress and chemistry were analyzed on other individuals from the same cohort.

Water quality was assessed at each sampling time. The physicochemical quality of Bizerte lagoon waters was monitored in situ. Salinity $\left(\mathrm{g} .1^{-1}\right)$, temperature $\left({ }^{\circ} \mathrm{C}\right)$, dissolved oxygen $\left(\mathrm{mg} . \mathrm{l}^{-1}\right)$ and $\mathrm{pH}$ were measured at the sampling sites using a Multi 350i Multimeter.

\section{Chemical analyses}

\section{Determination of PAH content}


201 Three distinct pools were prepared ( 1 pool $=3$ digestives glands). PAH content in the digestive 202 gland fractions was determined by gas chromatography (GC) coupled with mass spectrometry $22_{4}^{3} 3$ (MS), based on a protocol described by Baumard and Budzinski (1997). An HP GC (HewlettPackard, Palo Alto, California, USA), equipped with a split/splitless injector, was used. PAHs were quantified relative to perdeuterated PAHs (Baumard and Budzinski 1997). The response factors of the various compounds were measured by injecting a standard reference material solution (SRM 2260 (24 aromatic hydrocarbons in toluene) (NIST, Gaithersburg, Maryland, USA), spiked with the same solution containing perdeuterated PAHs as that used for spiking mussel digestive glands. The detection limits for PAH congeners was approximately $50 \mathrm{pg} / \mathrm{g}$. Results were expressed in $\mu \mathrm{g} / \mathrm{g}$ dry weight.

\section{Determination of PCB content}

A standard mixture of twelve PCB congeners (PCB-18, 28, 31, 52, 44, 101, 149, 118, 153, 138, 180 and 194) at $10 \mu \mathrm{g} \mathrm{mL}^{-1}$ in heptane was purchased from Supelco (CIL, USA). These standard solutions were further diluted by $n$-hexane to obtain mixed fortifying and GC calibration standard solutions for all compounds.

PCB compounds were analyzed using the method described by Guo et al., 2008. Freeze-dried digestive gland tissue (10 g) was Soxhlet-extracted with $n$-hexane:acetone $(4: 1 ; \mathrm{v} / \mathrm{v})$ for $16 \mathrm{~h}$ at a rate of five cycles per hour. The extract was concentrated using a rotary evaporator. An aliquot of $1 \mathrm{~mL}$ was used for gravimetric determination of the extractable lipid content. The remaining lipids were removed by treatment with concentrated sulfuric acid $(4 \times 10 \mathrm{~mL})$, after adding BDE77 as internal standard. In addition, a clean-up was performed on a column $(40 \times 0.5 \mathrm{~cm} \mathrm{ID)}$ packed with $5 \mathrm{~g}$ of activated Florisil and topped with $1 \mathrm{~g}$ of anhydrous sodium sulfate. The extract was eluted with $50 \mathrm{~mL}$ of dichloromethane and $n$-hexane $(1: 9 ; \mathrm{v} / \mathrm{v})$. The eluate was finally concentrated in a Kuderna-Danish to $0.5 \mathrm{~mL}$ and was then ready for instrumental analysis. The limit of detection, calculated as three times the signal to noise ratio, ranged from 500 to $1,000 \mathrm{pg} \mathrm{g}^{-1}$ lipid weight for PCBs. Results were expressed in ng/g dry weight.

\section{Determination of heavy metal content}

Digestive gland tissue (five distinct pools prepared as described below) was thawed and dried at $508^{\circ} \mathrm{C}$ to a constant weight. Digestion of the samples was performed in a microwave oven (CEM-MDS 81D), in high-pressure vessels with concentrated nitric acid (Amiard et al. 1987). $\mathrm{Cd}, \mathrm{Cu}, \mathrm{Zn}$ and $\mathrm{Ni}$ concentrations were determined by atomic absorption spectrophotography with an acetylene flame for $\mathrm{Cu}$ and $\mathrm{Zn}$, and a graphite furnace for $\mathrm{Cd}$ and $\mathrm{Ni}$ (Amiard et al. 
1987). Internal controls, based on standard reference materials with certified metal content, together with international intercalibration exercises, were carried out to validate this procedure. The limit of detection of $\mathrm{Cd}, \mathrm{Cu}, \mathrm{Zn}$ and $\mathrm{Ni}$ was $0.05 \mathrm{mg} . \mathrm{g}^{-1}$ wet weight. Results were expressed in $\mu \mathrm{g} / \mathrm{g}$ dry weight.

\section{Physiological indexes}

The Condition Index (CI) was determined as an indicator of mussel physiological status. CI is an ecophysiological measurement of animal health that summarizes physiological activity (growth, reproduction, secretion etc.) in given environmental conditions.

Shell thickness, length and width were measured using a $0.05 \mathrm{~mm}$ precision caliper as described by Fisher, Schneider, and Bauchot (1987). Once the biometric measurements had been completed, the valves of each individual (30 specimens) were opened carefully and all tissue was removed from the shells. Before weighing, excess moisture was removed from all parts of the animals using absorbent paper. After recording total weight and visceral mass wet weight, the tissue was then dried at $70^{\circ} \mathrm{C}$ for $48 \mathrm{~h}$.

The Condition Index (CI) was calculated as follows:

$\mathrm{CI}=\mathrm{MDW} /(\mathrm{TW}-\mathrm{SDW}) * 100$ (Lucas and Beninger, 1985)

Whereby MDW is meat dry weight $(\mathrm{g})$, TW is total weight and SDW is shell dry weight (g).

\section{Stress on stress}

The survival in air (SoS) test was performed on 30 animals from each site on their arrival at the laboratory, using the method described by Viarengo et al. (1995). The mussels were placed in a plastic box at a constant room temperature of $18 \pm 1{ }^{\circ} \mathrm{C}$ with less than $100 \%$ humidity. Mortality was checked daily. Mussels were considered dead when they did not produce any response to an external stimulus, after their valves gaped, or they did not react when placed in sea water. Results were expressed in number of survival days.

\section{Biochemical Analysis}

Ten mussels $(n=10)$ from each site were analyzed individually for each biomarker measurement.

Prior to biochemical analysis, the digestive glands were homogenized in a phosphate buffer $(0.1$ $\mathrm{M}$ [pH7.5]). The resulting homogenate was centrifugated at $100,000 \mathrm{~g}$ for microsomal fractions and 9,000 $\mathrm{g}$ for cytosolic fractions (S9). The quantities of proteins present in the microsomal 
fractions and S9 fraction were determined according to the Bradford (1976) method, using Coomassie Blue reagent (BioRad).

Benzo[a]pyrene hydroxylase (BPH): each pool of microsomal fractions of digestive glands was prepared at $4^{\circ} \mathrm{C}$ using differential centrifugation, as described by Michel et al. (1994). The quantity of S9 proteins was determined on the basis of the obtained supernatant (S9), according to the Bradford method (1976), using bovine serum albumin as standard. BPH activity was then assayed in the presence of nicotinamide adenine dinucleotide phosphate (NADPH), using the fluorimetric assay of Michel et al. (1994), as adapted to the microplate reader by Akcha et al. (2000). Results were expressed in $\mathrm{nmol} \mathrm{min}^{-1} \cdot \mathrm{mg}^{-1}$ proteins.

Glutathione S-transferase (GST) activity was measured in digestive gland cytosol according to the method of Habig et al. (1974), using $10 \mathrm{lg}$ cytosolic protein CDNB (Sigma-Aldrich Chemical, St. Louis, MO) as a substrate and glutathione reduced-form GSH (1 and $4 \mathrm{mM}$ final concentrations, respectively) in a $100 \mathrm{mM}$ sodium phosphate buffer (pH 7.5). GST activity was determined by kinetic measurement at $20^{\circ} \mathrm{C}$ using a Jenway 6105 spectrophotometer $(\mathrm{k}=340$ $\mathrm{nm})$. Results were expressed as $\mu \mathrm{mol} \mathrm{GSH}-\mathrm{CDNB}$ produced $/ \mathrm{min} / \mathrm{mg}$ protein.

Catalase (CAT) was determined using the Clairbone method (Clairbone 1985). The reaction mixture (final volume $1 \mathrm{~mL}$ ) contained $0.78 \mathrm{~mL} 0.1 \mathrm{M}$ phosphate buffer $(\mathrm{pH} 7.5)$ and $0.2 \mathrm{~mL} 0.5$ $\mathrm{mM} \mathrm{H}_{2} \mathrm{O}_{2}$. After $30 \mathrm{~s}$ of preincubation, a reaction was triggered by adding $0.02 \mathrm{~mL}$ of the (S9) solution containing CAT fractions. CAT activity was assessed by kinetic measurement at $20^{\circ} \mathrm{C}$ using a Jenway 6105 spectrophotometer $(\mathrm{k}=240 \mathrm{~nm})$. Results were expressed as $\mu$ mol hydrogen peroxide transformed $/ \mathrm{min} / \mathrm{mg}$ protein.

Lipid peroxidation was estimated in terms of thiobarbituric acid reactive species (TBARS), with the use of 1, 1, 3, 3-treaethyloxypropane as standard. The reaction was assessed at $532 \mathrm{~nm}$ using TBA reagent as described by Buege and Aust (1978). MDA content was expressed as nmol equivalent $\mathrm{MDA} / \mathrm{mg}$ protein.

Acetylcholinesterase (AChE): gill tissues were homogenized in a phosphate buffer $(0.02 \mathrm{M}, \mathrm{pH}$ 7, Triton X 100, 1/2 w/v), then centrifugated at 9,000 $\mathrm{g}$ for $20 \mathrm{~min}$ at $4{ }^{\circ} \mathrm{C}$. The supernatant (S9) was used to determine AChE activity using the modified method of Ellman et al. (1961) by Bocquené et al. (1993). Protein concentration was determined with the Bradford (1976) method, using bovine serum albumin as standard. Results were expressed in $\mu$ mol. $\mathrm{min}^{-1} . \mathrm{mg}^{-1}$ protein.

Multixenobiotic resistance (MXR) proteins was determined with the Western blot method (Minier et al. 2000), using an anti-hamster Pgp C219 monoclonal antibody (Centocor 
Diagnostics, Malvern, PA, USA) and an alkaline phosphatase-conjugated goat anti-mouse IgG (Sigma).

Metallothionein content (MT) was evaluated using the spectrophotometric method described by Viarengo et al. (1997), based on cysteine residue titration of a partially-purified MT extract. MT protein levels were determined with a spectrophotometric assay for MTs, using Ellman's reagent ( $0.4 \mathrm{mmol} / \mathrm{L}$ DTNB in $100 \mathrm{mmol} / \mathrm{L} \mathrm{KH}_{2} \mathrm{PO}_{4}$ ) at $\mathrm{pH} 8.5$ in a solution containing $2 \mathrm{~mol} / \mathrm{L} \mathrm{NaCl}$ and $1 \mathrm{mmol} / \mathrm{L}$ EDTA. Reduced GSH standard solutions were used for calibration (2-100 $\mathrm{mmol} / \mathrm{L}$ ) and data was expressed in micrograms MT per milligram protein, taking into consideration mussel MT molecular weight and number of cysteine residues (21 residues) (Viarengo et al. 1997).

\section{Integrated biomarker response determination}

The biomarkers were then considered simultaneously by calculating the renewed version of the Integrated Biomarker Response (Beliaeff and Burgeot. 2002) by Devin et al. 2013. Once the standardized value of each biomarker had been calculated, all possible circular permutations of the $\mathrm{k}$ biomarkers were computed. This resulted in a matrix of IBR values, enabling calculation of the median IBR for a site and cross-site comparison of IBR values.

\section{$B A C$ and EAC determination}

Background assessment criteria (BAC) and environmental assessment criteria (EAC) were drawn up using the 10th and 90th percentiles of data. BAC was estimated using data from Site 2 (least-contaminated site and lowest temperature) and described background level threshold values. EACs are recently derived from toxicological data or expert knowledge and indicate a significant risk to the organism (Davies and Vethaak. 2012). In our study, EAC were calculated during the highest temperatures and at the most-contaminated site S1.

\section{Statistical Analysis}

The experimental data was initially tested for normality and homogeneity of variance, in order to meet statistical demands. Data was expressed as mean \pm standard deviation (SD). Data statistical analysis was performed using one-way analysis of variance (ANOVA) and Duncan's test for multiple range comparison $(\rho<0.05)$ was considered as significant. Different letters $(a, b)$ indicated significant differences between groups. The Pearson correlation coefficient was also calculated in order to study the relationships between the various biochemical and chemical 
analyses. Differences in mussel size between the two sites were evaluated using Student test ( $\rho$ $<0.05$ ) for each sampling date. All biological, chemical and physico-chemical data were further subjected to principal component analysis (PCA), this analysis was used to discriminate the abiotic parameters effects on biological response in mussels from two sites in the lagoon. eighteen variables were taken into consideration: concentrations of for traces metals, $\Sigma$ PAHs and $\Sigma$ PCB concentrations, physico-chemical parameters (Oxygen dissolved, salinity, and seawater temperature), seven biomarkers (BPH, CAT, GST and AChE activities, MXR, TBARS and MT levels), as well as the condition and the gonadic indices of mussels. All statistical tests were performed using the Statistica 6 software package (StatSoft, USA).

\section{Results}

\section{Monitoring of environmental parameters}

Environmental parameters revealed changes in water quality according to sampling time (Table 1). Water temperature increased in Bizerte lagoon during the study period and a marked increased in temperature (i.e. $+11^{\circ} \mathrm{C}$ ) was observed between May and August 2011. In a corresponding way, a significant increase in lagoon salinity was recorded in August (37.8 psu) versus May (32 psu). The lowest concentration of dissolved oxygen was recorded in August ( 6.2 mg. $\left.\mathrm{L}^{-1}\right)$. This decrease in dissolved oxygen concentration was the result of an increased Chlorophyll a concentration. Indeed, Chlorophyll a concentrations in lagoon waters were found to be higher in August (3.642 $\left.\mu \mathrm{g} . \mathrm{L}^{-1}\right)$ than in May $\left(2.185 \mu \mathrm{g} . \mathrm{L}^{-1}\right)$. The increases in temperatures and salinity, associated with a relative decrease in dissolved oxygen we observed during the summer months, is favourable to the eutrophication of Bizerte lagoon (Khessiba et al. 2005). There were no variations in $\mathrm{pH}$, turbidity, nitrite, nitrate, ammonia and silicate concentrations throughout the study period exept $\mathrm{pH}$ with decrease of 0.5 .

\section{Chemical analyses}

Trace metal concentrations in mussel digestive glands showed both temporal and spatial variations. Generally speaking, metal concentrations $(\mathrm{Cd}, \mathrm{Cu}, \mathrm{Zn}$ and $\mathrm{Ni})$ as a whole were significantly higher in the digestive glands of mussels sampled from Site 1 versus Site $2(\rho<0.05)$ and contamination levels at the respective sites differed by a factor of 1.5. Metal trends were similar at both study sites (Figure 5), with the lowest values in May and the highest values in August. Moreover, concentrations of all metals were significantly correlated with water temperature $(\rho<0.05)$. 
All measured trace metals showed a significant correlation with MT accumulation at both sites. Cd was significantly correlated to MT $(r=0.59 ; \rho<0.05)$ and $(r=0.50 ; \rho<0.05)$, respectively at Sites 1 and 2. (Table 2). PCA analyses were performed to obtain a global vision of the results according to the mean values of pollutant levels in digestive gland, biomarker responses in mussel's tissues and physic- chemical parameters of water (Figure 5). Both sites showing that the accumulations of $\mathrm{Cd}, \mathrm{Cu}, \mathrm{Zn}$ and $\mathrm{Ni}$ were grouped and related to the water temperature. Almost all polycyclic aromatic hydrocarbon (PAH) compounds measured in digestive glands were three times higher in mussels from the Menzel Abdelrahmen site (Site 1) versus the Baie des Carrières site (Site 2). PAHs content was significantly higher in the digestive glands of mussels collected from Site 1 versus Site $2(\rho<0.05)$ (Table 2). The highest values of $\Sigma$ PAHs concentrations were found in August at Site $1\left(\Sigma \mathrm{PAHs}=2.03 \mu \mathrm{g} \cdot \mathrm{g}^{-1}\right.$ dry weight) and in July at Site 2 ( $\Sigma \mathrm{PAHs}=0.92$ $\mu \mathrm{g} \cdot \mathrm{g}^{-1}$ dry weight) (Table2.). $\Sigma$ PAHs concentrations were significantly correlated with water temperature at Site 1 only $(r=0.66 ; \rho<0.05)$. Total PAHs at Site 1 showed a significant correlation with the detoxification enzymes oh phase I BPH activity $(r=0.58 ; \rho<0.05)$ and phase II GST activity $(\mathrm{r}=-0.84 ; \rho<0.05)$.

Concentrations of polychlorinated biphenyls (PCBs) in digestive glands were significantly higher in mussels from Site 1 versus Site $2(\rho<0.05)$. The monthly trends of $\Sigma$ PCB at both sites were similar, with increased levels between May and August. The trends of each PCB compound were similar at both sites, with generally higher levels in May for PCB-18, PCB-52, PCB-44 and PCB-194 and in August for the remaining compounds. A significant correlation was found at both sites between PCB concentrations and CAT activity, with $(r=0.80 ; \rho<0.05)$ and $(r=0.48$; $\rho<0.05$ ) respectively at Sites 1 and 2 .

\section{Physiological parameters}

During the sampling period the size of the mussels showed no difference between the two study sites $(\rho<0.05)$ with $(\rho=0,594 ; \rho=0,786 ; \rho=0,879 ; \rho=0,724)$ respectively in May, June, July and August. Both stations appear homogeneous with a seamless growth factor inside the lagoon.

Physiological response to temperature changes was determined by examining condition and gonadic indexes (CI and GI). CI calculated during the study period remained constant in May and June, then showed a slight decrease in July, offset by an increase in August. However, these variations were not significant $(\rho<0.05)$ (Figure 2). In mussels sampled at Site 1, CI ranged from

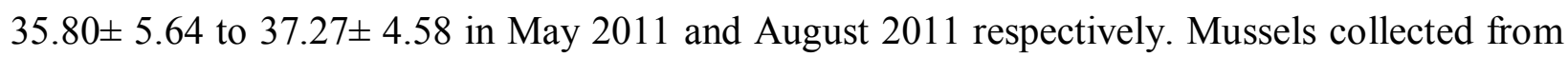
Site 2 showed condition indexes ranging from $38.33 \pm 7.16$ to $42.9 \pm 6.8$ during the study period. 
Similarly, there were no significant differences in GI throughout the sampling period at the two sites. Physiological parameters seems to be related to abiotic factors such as $\mathrm{pH}$ and dissolved oxygen in seawater (Figure 5).

Stress on stress curves and $\mathrm{LT}_{50}$ values for all sampling months at both study sites are reported in Figure 3. $\mathrm{LT}_{50}$ values ranged from 5 to 9 . No differences were observed across the study sites. Survival time was longer at both sites in May than in August. There were no significant physiological differences related to chemical contamination at the two stations. However, mussel metabolic adaptation response was naturally more intensive when the temperature was at its highest in August, hence apparently affecting the resilience of immersed mussels.

\section{Biotransformation enzymes}

The markedly high water temperature at our study sites appeared to influence the level of expression of all analyzed biomarkers. Indeed, the three studied biomarkers involved in biotransformation mechanisms (BPH, GST and MXR) revealed a very noticeable monthly variation starting in July, when the water temperature rose sharply from $19^{\circ} \mathrm{C}$ to $26^{\circ} \mathrm{C}$ (Table 1). In fact, BPH activity measured in the digestive glands of mussels sampled from the Menzel Abdelrahmen site showed a very significant $(\rho<0.05)$ induction in August $(\mathrm{p}=0,00005)$, when the water temperature reached $29^{\circ} \mathrm{C}$ (Figure 4A). BPH activity was significantly higher $(\rho<0.05)$ in animals sampled from the Menzel Abdelrahmen site (Site 1) versus Site 2 ( $F=23,1747$; $\mathrm{p}=0,0001)$. The highest values $\left(0.31\right.$ and $0.27 \mathrm{nmole} \cdot \mathrm{mn}^{-1} \cdot \mathrm{mg}^{-1}$ proteins) were recorded at Site 1 in June and August respectively, but did not correspond to a progressive temperature elevation. No significant monthly variations were recorded at Site 2. BPH activity appears to be the most biomarker related to PAH accumulation (Figure 5), thus indicating the induction effect of PAH contamination on enzyme of phase I.

Variations in GST activity in mussel digestive glands were also observed during the study period. GST activity ranged from 91.8 to $176.8 \mu$ mole. $\mathrm{mn}^{-1} \cdot \mathrm{mg}^{-1}$. proteins at Site 1 and 129.8 to $157.9 \mu$ mole. $\mathrm{mn}^{-1} \cdot \mathrm{mg}^{-1}$ proteins at Site 2 (Figure 4B). GST decreased progressively as temperature increased. A significant difference in GST activity at both sites was also observed in June $\left(\rho_{1}=0.000021 ; \rho_{2}=0.0236\right)$ and August $\left(\rho_{1}=0.000025 ; \rho_{2}=0.0010\right)$ respectively for site 1 and site 2 .

MXR protein expression in the gills of mussels collected monthly in late spring and summer appeared to be more affected by water temperature elevation in August (Figure 4C). MXR protein levels were significantly lower at Site 2 than at the more contaminated Site $1 \quad(\rho<0.05)$ $(\mathrm{F}=50.930 ; \mathrm{p}=0.000001)$. The highest levels were observed in August at both sites, with 218.4 $\mathrm{OD} / \mu \mathrm{g}$ proteins and $125.9 \mathrm{OD} / \mu \mathrm{g}$ proteins at Sites 1 and 2 respectively. 


\section{Oxidative stress}

Oxidative stress biomarkers were highest when water temperature was at its highest in July and August. Moreover, CAT activity was significantly higher in the digestive glands of M.galloprovincilais collected from both sites in July and August (Figure 4F). CAT activity ranged from 159.8 to $375.6 \mu$ mole. $\mathrm{mn}^{-1} \cdot \mathrm{mg}^{-1}$ proteins at Site 1 and from 153.6 to 340.4 $\mu$ mole. $\mathrm{mn}^{-1} . \mathrm{mg}^{-1}$ proteins at Site 2 . The amplitude of response was similar from May to June and no clear inter-site trends were observed during the study period.

MDA accumulation (Figure 4E), evaluated as TBARS in mussel digestive glands, differed significantly at the two sites $(\rho<0.05)(\mathrm{F}=15.285 ; \mathrm{p}=0.001)$. At Site 1 , MDA accumulation ranged from 2.6 to 4.9 nmole. $\mathrm{mg}^{-1}$ proteins and the highest value was recorded in August. At Baie des Carrières (Site 2), MDA content was homogenous and increased progressively according to temperature. No significant temporal variations were observed.

\section{Neurotoxicity}

AChE activity measured in M.galloprovincialis gills (Figure 4G) showed this biomarker to be significantly inhibited in mussels sampled in July and August versus those sampled in late spring (May and June). AChE activity ranged from 21.5 to $60.3 \mu$ mole. $\mathrm{mn}^{-1} . \mathrm{mg}^{-1}$ proteins in the gills of mussels from Site 1 and from 40.1 to $61.2 \mu$ mole. $\mathrm{mn}^{-1} . \mathrm{mg}^{-1}$ proteins in the gills of mussels from Site $2(\mathrm{~F}=18.893 ; \mathrm{p}=0.00038)$. The amplitude of response was higher at the more contaminated Site 1. A significant difference was observed in AChE activity in mussels sampled from Site 1 versus Site 2 during the summer months (June, July and August 2011) $(\rho<0.05)$. Lower levels of activity were detected in mussels sampled from Site 1 and significant differences were also recorded during the biomonitoring survey conducted at the same site.

\section{Metal-related stress}

MT accumulation (Figure 4D) evaluated in mussel digestive glands revealed significant temporal variations. The temperature-dependent accumulation of MT was shown to be more pronounced in animals sampled from both sites in August. MT concentrations in the digestive glands of mussels from Site 1 were significantly higher than in those from Site 2 throughout the study period $(\rho<0.05)(\mathrm{F}=46.526 ; \mathrm{p}=0,000002)$. MT content ranged from $126.54 \mu \mathrm{g}_{\mathrm{mg}} \mathrm{m}^{-1}$ proteins in May to 203.95 in August and from $64.77 \mu \mathrm{g} \cdot \mathrm{mg}^{-1}$ proteins in May to 150.29 in August in the digestive glands of mussels from Site 1 and Site 2 respectively. MT response appeared to be month-related at both sites, with lower values observed in May versus August. 


\section{IBR index}

The IBR index demonstrates an increase of the metabolic response in relation with the temperature (Fig 6) and secondly with the salinity in the two sites 1 and 2. The lowest IBR values (from 2 to 6 ) were calculated in the two sites when the temperature is less than $18^{\circ} \mathrm{C}$, in May and June. The IBR index increase greatly from June to August when the temperature raise from $19^{\circ} \mathrm{C}$ to $29^{\circ} \mathrm{C}$. The greatest increase of IBR (from 5 to 19.6) is obtained in the most contaminated site 1 when the highest temperature and the highest chemical contamination are cumulated.

\section{Discussion}

The purpose of this study was to quantify the biological effects of the highest summer water temperatures on biomarker responses analyzed in mussels from Bizerte lagoon at two sites with differing degrees of chemical contamination (PAHs, PCBs, trace metals). Various works have reported a close relationship between thermal stress and biomarker response in marine molluscs (Regoli 1992; Domouhtsidou and Dimitriadis. 2001; Moore et al. 2006a, 2007; Zhang et al. 2006). In our study, significant alterations to biochemical markers were observed in mussels sampled from the most-contaminated Site 1 versus Site 2. Indeed, biomarker responses in M.galloprovincialis showed clear temporal and spatial variations. Temperature has been considered as the primary factor affecting natural enzyme activity (Leiniö and Lehtonen. 2005); and salinity can be considered as a second factor in the Bizerte lagoon. These variations therefore probably reflect environmental parameter changes associated with contaminant bioavailability. The biological availability and toxicity of trace metals are determined by their chemical speciation which is dominated by organic complexation along a gradient of salinity in estuary (Money et al., 2011) 
(Eertman et al. 1993). Various studies have demonstrated that bivalves exposed to contaminants have reduced tolerance to anoxia (Viarengo et al. 1995). We found a similar level of resistance and a clear-cut monthly pattern at both sites. However, decreased resistance was revealed in August, in particular in mussels from Site 1, confirming that this site is more extensivelyaffected by chemical contaminants such as metals, PAHs and PCBs, although reproductive cycles and variations in body reserves should also be taken into account. Lagoon mussels undergo a period of sexual inactivity in July and August (Banni et al. 2011), so that body reserves and, in particular, glycogen derived from food easily available in lagoon waters in this season (Bressan and Marin. 1985) can be used to better withstand stresses caused by air exposure. These factors may significantly reduce the responsiveness of the survival-in-air parameter.

The cytochrome P450 family, belonging to Phase I (functional reactions) and GST, involved in Phase II (conjugative reactions) of the biotransformation process, are the main enzymes used as biomarkers of organic pollutant detoxification (Regoli et al. 2002). Phase I and Phase II detoxification mechanisms were therefore investigated in our study by evaluating BPH and GST activity (Figure 5). We reported a significant increase in BPH activity in animals sampled from Site 1 in June and August versus animals from Site 2. This increase in the Phase I biotransformation process hence correlated with increased $\Sigma$ PAH bioaccumulation in June and August. Inhibited GST activity at both sites was higher in June and August in the site 1 comparatively to the BPH induction. In this case the phases I and II seems indicates the same metabolic effort of detoxification (Figure 4).

MXR protein levels were significantly higher at Site 1 than Site 2 throughout the study period. This could be explained by the contamination levels found in mussels from Site 1 (Menzel Abdelrahmen) (fig $1 \mathrm{C}$ ). MXR prevents the bioaccumulation of toxic xenobiotics or endogenous metabolites by transporting them out of the cell (Minier and Moore. 1996). The increase in MXR protein levels in August can be explained by the increased water temperature. Indeed, abiotic factors such as temperature (Minier et al. 2000) and organic pollutants have been shown to affect MXR protein levels, as we observed in M.galloprovincialis. In this case, the phase III of detoxification is not correlated with the phases I and II.

Oxidative stress biomarkers in M.galloprovincialis showed spatial variability, with significant MDA accumulation in mussels from Site 1 versus Site 2 throughout the study period, whereas CAT activity was significantly higher in August only. The activity of CAT - a primary enzyme in the antioxidant defence system and often one the earliest antioxidant enzymes to be induced 
535 (Capello et al. 2013) - was also investigated in this study. CAT values showed temporal fluctuations at both study sites. These biological responses may also be modulated by seasonal changes in both environmental and biological factors, potentially influencing responsiveness and sensitivity to pollutants (Dellali et al. 2001). Our results were in total agreement with the fluctuations in CAT activity according to temperature found in M.galloprovincialis mussels and Ruditapes decussatus clams in Bizerte lagoon (Dellali et al. 2001). Pellerin-Massicotte (1994, 1997) reported increased CAT antioxidant activity as being associated with increased lipid peroxidation at high temperatures in Mytilus edulis blue mussels. MDA levels are proportional to the extent of lipid peroxidation (Aust. 1985) and act as a marker for membrane lipid oxidation. Numerous studies have underlined MDA concentration as a major parameter for assessing oxidative stress in organisms (Roméo and Gnassia-Barelli. 1997). MDA levels in M.galloprovincialis sampled from Site 1 were highest in August. This increase appears to be due to an increase in heavy metals, inducing lipid peroxidation (Avery et al. 1996). Wastewater from numerous sewers is discharged directly into the eastern sector of the lagoon; the city of Menzel Abdelrahmen may also be responsible for enriching Site 1 with various pollutants (Mahmoud et al. 2010). In general, organisms with a reduced antioxidant status may be more prone to lipid peroxidation and therefore have higher MDA levels (Cossu et al. 2000).

From June onwards, AChE activity measured in the gills of mussels sampled at Baie des Carrières (Site 2) was slightly higher than at the Menzel Abdelrahmen (Site 1). Neurotoxic pesticides such as carbamates, organophosphates and pyrethrins are known to exert an inhibitory effect on AChE activity (Bocquené et al. 1993; Binelli et al. 2005). Other classes of compounds, such as heavy metals (Lionetto et al. 2003), may influence the AChE activity of an organism by altering the pathway of enzyme synthesis, or simply by affecting the general health of the organism by reducing enzyme production. This suggests an extensive domestic use of potential pollutants such as pesticides in summer. Indeed, AChE activity is commonly used to diagnose pesticide exposure in environmental monitoring studies (Mora et al. 1999; Davies et al. 2001), but can also be indirectly inhibited by other organic compounds.

Metallothionein (MT) measurements have been widely used to assess the effects of metal pollution in both laboratory (Viarengo et al. 1997) and field studies (Serafim and Bebianno. 2001). In this study, we reported a significant increase in MT levels in the digestive glands of mussels sampled from Site 1 versus Site 2. Temporal variations in MT levels at both sites were significantly correlated with water temperature, as previously shown by Sefarim et al. (2002).

The salinity could also influence the MT levels because the biological availability and toxicity of trace metals are determined by their chemical speciation which is dominated by organic 
complexation along a gradient of salinity in estuary (Money et al., 2011). The salinity variation (hypoosmotic stress) in the marine environment can affect lot of biomarkers as MT, oxygen consumption rate and survival in air (SoS test) in M. Gallorpovincialis (Hamer et al., 2008) (Figure 5)

We observed a clearly significant spatial difference in the accumulation rate of MDA, MT and MXR for all measured biomarkers during the study period, although the highest values were measured in mussels from the Menzel Abdelrahmen site. Moreover, mussels from this site appeared to be more vulnerable to and affected by the higher water temperatures in July and August. This could be explained by the combined effect of chemical contamination at this site and higher temperatures in summer.

The IBR constitutes a practical and robust tool for assessing sensitivity to contaminants using combined biomarker responses. The IBR can be used to reflect the biological effects of contamination measured at various sites, regardless of variations in the biomarker sets used for index calculations (Beliaef and Burgeot. 2000, Sefarim et al. 2012). In our study, application of the IBR allowed us to identify the most highly-impacted site. The two sites studied in Bizerte lagoon (Sites 1 and 2) showed marked temporal and spatial variations (Figure 5). The IBR index showed biomarker responses to be higher in July and August at both sites. At Site 1, all measured biomarkers were shown to be significant with regards to overall biochemical response. IBR elevation was particularly significant between June and July. When the temperature rose from $19^{\circ} \mathrm{C}$ to $26^{\circ} \mathrm{C}$, the IBR increased from 5 to 18 at Site 1 . These results highlighted Menzel Abdelrahmen (Site 1) as being the most highly-impacted site. Furthermore, correlation analysis showed a highly significant correlation between the IBR index and water temperature $(r=0.661$; $\mathrm{r}=0.519$ ), respectively at Sites 1 and 2. The strong fluctuation of the biological response observed with the IBR index allowed us to characterize a maximal metabolic effort in August in the site 1 and a minimal metabolic effort in May in the site 2 (Figure 6). In this study, both BAC and EAC thresholds were calculated according to the OSPAR approach (Davis and Vethaak. 2012) for caged mussels collected from a lagoon (Table 3). We calculated BAC based on the two study sites in Bizerte lagoon and our chemical data and biomarker results, considering Baie des Carrières (Site 2) as the least-contaminated site. EACs were calculated during the highest temperatures and highest metabolic response in August and at the most-contaminated Site 1 (Menzhel A.). Only two thresholds (AChE and SoS) determined in Bizerte lagoon could be compared with the OSPAR thresholds for M.galloprovicialis mussels. The background response of acetylcholinesterase in M.galloprovincialis mussels in Bizerte lagoon derived from OSPAR 
2012 data (study performed on M.galloprovincialis wild mussels in the Mediterranean Sea (Spain) in the same season (Campillo-Gonzalez, pers. comm in 2012 ICES report)). This difference $\left(\right.$ EAC OSPAR $=10$ nmol. $\mathrm{min}^{-1} \cdot \mathrm{mg}^{-1}$ proteins versus EAC Bizerte $=30$ nnmol.min ${ }^{1} . \mathrm{mg}^{-1}$ proteins), seen between two Mediterranean sites, highlights the need to adapt thresholds to different area typologies (i.e lagoon in North Africa and open sea in Spain). The determination of EAC and BAC in Bizerte lagoon is a first step towards defining thresholds at two sites with different chemical contamination during sharp temperature rises in North Africa. A more exhaustive definition is needed to express metabolic response magnitude for a full physiological cycle.

\section{Conclusion}

This study revealed that increased water temperatures in summer, combined with the presence of organic and inorganic contaminants, can directly influence the biological response of mussels. The combined increases of temperature and salinity exceptionally caused major variations in biomarkers at the most highly-contaminated site (Menzel Abdelrahmen). The biomarkers found to be the most sensitive to the combined effects of chemical contamination and high temperatures were AChE inhibition, the induction of CAT activities and a large accumulation of MT, MDA and MXR proteins. The highest metabolic response was confirmed in August, when differences in the IBR values of the least-contaminated Site 2 and the most-contaminated Site 1 were also highest. This preliminary study, conducted at a lagoon in northern Tunisia, allowed us to propose preliminary EAC and BAC over a specific period of high temperatures and high salinity, when metabolic response was at its most intense. Another more accurate and designated study to determine response thresholds in Bizerte lagoon mussels should be performed over the course of one or two complete physiological cycles. This approach demonstrated the value of choosing a sensitive period in the mussel life cycle to facilitate biomarker interpretation and biomonitoring in a North African lagoon.

\section{Acknowledgements}

This study was backed by the Ministry of Scientific Research and Technology, University of Sousse, Tunisia (Research Unit of Biochemistry and Environmental Toxicology UR 04AGR05), and the French Institute of Tunisia.

This study has been carried out in the framework of the Cluster of Excellence COTE.

\section{References}


Akcha F, Izuel C, Venier P, Budzinski H, Burgeot T, Narbonne J-F (2000) Enzymatic biomarker measurement and study of DNA adduct formation in benzo[a]pyrene-contaminated mussels, Mytilus galloprovincialis. Aquat Toxicol 49:269-287

Allan IJ, Vrana B, Greenwood R, Mills GA, Roig B, Gonzalez C (2006) A “toolbox" for biological and chemical monitoring requirements for the European Union's Water Framework Directive. Talanta 69:302-322

ANPE, (1990) Diagnostic préliminaire pour l'Etude de l'Equilibre Ecologique du lac de Bizerte.

Amri Z, Turki S, Trabelsi E, Ben Maiz N (2010) First recorded proliferation of Coolia monotis (Meunier, 1919) in the North Lake of Tunis (Tunisia) correlation with environmental factors. Environ Monitor and Assess 164: 423-433

Aust SD (1985) Lipid oxidation. In: Greenwald, R.A. (Ed.), CRC Handbook of Methods for Oxygen Radical Research. CRC Press Boca Raton FL :203-207

Avery E L, Dunstan RH, Nell JA, (1996) The detection of pollutant impact in marine environments: condition index, oxidative DNA damage, and their associations with metal bioaccumulation in the Sydney rock oyster Saccostrea commercialis. Arch Environ Contam Toxicol 31: 192-198

Banni M, Negri A, Dagnino A, Jebali J, Ameur S, Boussetta H (2010) Acute effects of benzo[a]pyrene on digestive gland enzymatic biomarkers and DNA damage on mussel Mytilus galloprovincialis. Ecotoxicol Environ Saf 73: 842-848

Banni M, Negri A, Mignone F, Boussetta H, Viarengo A, Dondero F (2011) Gene expression rhythms in the mussel Mytilus galloprovincialis (Lam.) across an annual cycle. PLoS One 6(5): e18904. doi:10.1371/journal.pone.0018904

Baumard P, Budzinski H (1997) Internal standard qualification method and gas chromatographmass spectrometer (GC-MS): a reliable tool for polycyclic aromatic hydrocarbon (PAH) quantification in natural matrices. Analusis 25: 246-252

Bebianno MJ, Langston WJ, (1992) Cadmium induction of metallothionein= synthesis in Mytilus galloprovincialis. Compara Pharmacol and Toxicol 103 (1): 79-85

Beji O (2000) Les ressources vivantes exportables du lac de Bizerte: Etat actuel et potentialités (première partie). Bull Inst Nat Sci Tech Mer Salammbô 27: 45-60

Beliaeff B, Burgeot T (2002) Integrated biomarker response (IBR): a useful graphical tool for ecological risk assessment. Environ Toxicol Chem 21:1316-1322

Ben Ameur W, Lapuente J, El Megdiche Y, Barhoumi B, Trabelsi S, Camps L, Serret J, RamosLópez D, Gonzalez-Linares J, Driss M, Borràs M (2012) Oxidative stress, genotoxicity and histopathology biomarker responses in mullet (Mugil cephalus) and sea bass (Dicentrarchus labrax) liver from Bizerte lagoon (Tunisia). Mar Pollu Bul 64: 241-251 
Ben Ameur W, BenHassine S, Eljarrat E, ElMegdiche Y, Trabelsi S, Hammami B, Barcelo D, $6 \square 3$ Driss MR (2011) Polybrominated diphenyl ethers and their methoxylated analogs in mullet (Mugil cephalus) and sea bass (Dicentrarchus labrax) from Bizerte lagoon, Tunisia. Mar Environ Res 72: 258-264

Ben Garali A, Ouakad M , Gueddari M (2010) Contamination of superficial sediments by heavy metals and iron in the Bizerte lagoon, northern Tunisia. Arabian J Geosci 3: 295-306

Binelli A, Ricciardi F, Riva C, Provini A (2005) Screening of POP pollution by AChE and EROD activities in zebra mussels from the Italian Great Lakes. Chemos 61:1074-1082

Bodin N, Burgeot T, Stanisière JY, Bocquené G, Menard D, Minier C, Boutet I, Amat A, Cherel Y, Budzinski H (2004) Seasonal variations of a battery of biomarkers and physiological indices for the mussel Mytilus galloprovincialis transplanted into the northwest Mediterranean Sea. Compar Bioch and Physiol Part C 138: $411-427$

Bolognesi C, Frenzilli G, Lasagna C, Perrone E, Roggieri P (2004) Genotoxicity biomarkers in Mytilus galloprovincialis: wild versus caged mussels. Muta Res 552: 153-162

Bocquené G, Galgani F, Burgeot T, Le Déan L, Truquet P (1993) Acetylcholinesterase levels in marine organism along french coasts. Mar Poll Bull 26: 101-106

Bradford MM (1976) A rapid and sensitive method for the quantification of microgram of protein utilizing the principal of protein-dye binding. Anal Bioch 72:248-254

Bressan M, Marin MG (1985) Seasonal variations in biochemical composition and condition index of cultured mussels (Mytilus galloprovincialis) in the Lagoon of Venice (North Adriatic). Aquacul 48: 13-21

Buege JA, Aust SD (1978) Microsomal lipid peroxidation. Meth Enzymol 52:302-310

Burgeot T, Faucet J , Ménard D, Grosjean P, Bocquené G (2006). Variations of benzo(a)pyrene hydroxylase and cholinesterase activities in mussels caged in the North Sea (German Bight and Statfjord). Special Issue. Environmental Toxicology and chemistry. 171-185.

Cappello T, Maisano M, D'Agata A, Natalotto A, Mauceri A, Fasulo S (2013) Effects of environmental pollution in caged mussels (Mytils galloprovincialis). Mar Envr Reaserch In press.

Charissou AM, Cossu-Leguille C, Vasseur P (2004) Relationship between two oxidative stress biomarkers, malondialdehyde and 8-oxo-7,8-dihydro- 2'-deoxyguanosine, in the freshwater bivalve Unio tumidus. Sci Tot Environ 322: 109-122

Cheikh M, Derouiche A, Driss MR (2002) Détermination par (CPG-ECD) des résidus de pesticides organochlorés dans les sédiments de la lagune de Bizerte. Bull Inst Nat Sci Technol Mer 7: 160-163

Cheung CC, Zheng GJ, Li AM, Richardson BJ, Lam PK (2001) Relationships between tissue concentrations of polycyclic aromatic hydrocarbons and antioxidative responses of marine mussels, Perna viridis. Aquat Toxicol 52: 189-203 
Clairbone A (1985) Catalase activity. Handbook of methods for oxygen radical research. CRC Press Boca Raton : 283-284

Cossu C, Doyotte A, Babut M, Exinger A, Vasseur P, (2000) Antioxidant biomarkers in freshwater bivalves, Unio tumidus, in response to different contamination profiles of aquatic sediments. Ecotoxicol Environ Saf 45: 106-121

Dailianis S, Domouhtsidou GP, Raftopoulou E, Kaloyianni M, Dimitriadis VK (2003) Evaluation of neutral red retention assay, micronucleus test, acetylocholinesterase activity and a signal transduction molecule (cAMP) in tissues of Mytilus galloprovincialis (L.) on pollution monitoring. Mar Environ Res 56: 443-470.

Davies I M, Rodger G, Redshaw J, Stagg R M (2001) Targeted environmental monitoring for the effects of medicines used to treat sea-lice infestation on farmed fish. ICES J Mar Sci 52: 447485

Davies I M, Vethaak D (2012) Integrated marine environmental monitoring of chemicals and their effects. ICES cooperative research report 315

Dellali M, Roméo M, Aissa P (2001) Suivi annuel de l'activité catalase chez des moules et des palourdes originaires de la lagune de Bizerte. Ocean Acta 24: 1-9

Depledge MH (2009) Novel approaches and technologies in pollution assessment and monitoring: A UK perspective. Ocean Coast Manag 52:336-341

Derouiche A, Sanda YG, Driss M R (2004) Polychlorinated biphenyls in sediments from Bizerte lagoon, Tunisia. Bul Environ Contam Toxicol 73: 810-817

Devin S, Burgeot T, Giambérini L, Minguez L. and Pain-Devin S (2013) The Integrated Biomarker Response revisited: optimization to avoid misuse. Environ Sc Pollu Res . In press

Domouhtsidou GP, Dimitriadis VK (2001) Lysosomal and lipid alterations in the digestive gland of mussels, Mytilus galloprovincialis (L.) as biomarkers of environmental stress. Environ Pollu 115: $123-137$

Eertman RHM, Wagenvoort AJ, Hummel H, Smaal A C (1993) Survival in air of the blue mussel Mytilus edulis L. as a sensitive response to pollution-induced environmental stress. J Experim Marin Biol and Ecol170: 179-195

Ellman GL, Courtney KO, Andres V, Featherstone RM., 1961. A new and rapid colorimetric determination of acetylcholinesterase activity. Biochem Pharmacol 7:88-95

Ennaceur S, Driss MR (2010) Serum organochlorine pesticide and polychlorinated biphenyl levels measured in delivering women from different locations in Tunisia. Int $J$ Environ Anal Chem: $821-828$

Fisher W, Schneider M, Bauchot ML (1987) Fiches FAO d'identification des especes pour les besoins de la peche: Mediterranee et Mer Noire. Vol. I, Végétaux et invertebrés. Rome, FAO 
Galloway TS, Brown RJ, Browne MA, Dissanayake A, Lowe D, Jones MB, Depledge MH (2004a) A multibiomarker approach to environmental assessment. Environ Sc Technol 38: 17231731

Gomiero A, Da Ros L, Nasci C, Meneghetti F, Spagnolo A, Fabi G (2011) Integrated use of biomarkers in the mussel Mytilus galloprovincialis for assessing off-shore gas platforms in the Adriatic Sea: Results of a two year biomonitoring program. Mar Pollu Bul 62: 2483-2495

Guo L, Qiu Y, Zhang G, Zheng GJ, Lam PK, Li X (2008) Levels and bioaccumulation of organochlorine pesticides (OCPs) and polybrominated diphenyl ethers (PBDEs) in fishes from the Pearl River estuary and Daya Bay, South China. Environ Pollu 152: 604-611

Habig W, Pabst M, Jakoby W (1974) Glutathione S-transferases. The first enzymatic step in mercapturic acid formation. J Biol Chem 249: 7130-7139

Hamer B, Jak Z, Hamer D P, Peri P, Medakovi D, Ivankovi D, Pavi P, Zilberberg C, Schroderd H, Mullerd WEG Smodlaka N, Batel R (2008) Effect of hypoosmotic stress by low salinity acclimation of Mediterranean mussels Mytilus galloprovincialis on biological parameters used for pollution assessment. Aquatic Toxicology 89 ; 137-151

ICES (2010b) Report of the working Group on Biological Effest of Contaminants (WGBC), 11 15 January, 2010, Dublin, Ireland. ICES Document CM2011/SSGHIE:04

Jarry V, Fiala M, Frisoni GF, Jacques G, Neveux J, Panouse M (1990) The spatial distribution of phytoplankton in a Mediterranean lagoon (Étang de Thau). Oceanologia Acta 13: 503-512

Kamel N, Attig H, Dagnino D, Boussetta H, Banni M (2012) Increased Temperatures Affect Oxidative Stress Markers and Detoxification Response to Benzo[a]Pyrene Exposure in Mussel Mytilus galloprovincialis. Arch Environ Contam Toxicol. DOI 10.1007/s00244-012-9790-3

Khessiba A, Hoarau P, Gnassia-Barelli M, Aissa P, Roméo M (2001) Biochemical Response of the Mussel Mytilus galloprovincialis from Bizerta (Tunisia) to Chemical Polluant Exposure. Arch Environ Contam Toxicol 40: 222-229

Khessiba A, Hoarau P, Gnassia-Barelli M, Aissa P, Roméo M (2001) Biochemical response of the mussel Mytilus galloprovincialis from Bizerta (Tunisia) to chemical pollutant exposure. Arch Environ Contam Toxicol 40: 222-229

Khessiba A, Roméo M, Aissa P (2005) Effects of some environmental parameters on catalase activity measured in the mussel (Mytilus galloprovincialis) exposed to lindane. Environ Pollu 133: $275-281$

Leiniö S, Lehtonen K (2005) Seasonal variability in biomarkers in the bivalves Mytilus edulis and Macoma balthica from the northern Baltic Sea. Comp Bioch Physiol C 140: 408-421

Lionetto MG, Caricato R, Giordano ME, Pascariello MF, Marinosci L, Schettino T (2003) Integrated use of biomarkers (acetylcholinesterase and antioxidant enzyme activities) in Mytilus galloprovincialis and Mullus barbatus in an Italian coastal marine area. Mar Pollut Bull 46:324330 
Livingstone DR (2001) Contaminant-stimulated reactive oxygen species production and oxidative damage in aquatic organisms. Mar Pollut Bull 42:656-66

Lowe D M, Pipe R K (1994) Contaminant induced lysosomal membrane damage in marine mussel digestive cells: an in vitro study. Aqua Toxicol 30: 357-365

6

Lucas A, Beninger P G (1985) The use of physiological condition indices in marine bivalve aquaculture. Aquaculture $44: 187-200$

Mahmoud N, Dellali M, El Bour M, Aissa P, Mahmoudi E (2010) The use of Fulvia fragilis (Mollusca: Cardiidae) in the biomonitoring of Bizerta lagoon: A mutimarkers approach. Ecolo Indica 10: 696-702

McFadzen I, Eufemia N, Heath C, Epel D, Moore M, Lowe D (2000) Multidrug resistance in the embryos and larvae of the mussel Mytilus edulis. Mar Environ Res 50: 1-5

Mediterranean Action Plan (2011) Development of assessment criteria for hazardous substances in the Mediterranean. UNEP (DEPI)/MED WG. 365/Inf.8

Michel X, Salaün JP, Galgani F, Narbonne JF (1994) Benzo(a)pyrene hydroxylase activity in the marine mussel Mytilus galloprovincialis: a potential marker of contamination by Polycyclic Aromatic Hydrocarbon type compounds. Mar Environ Res 38: 257- 273

Minier C, Borghi V, Moore MN, Porte C (2000) Seasonal variation of MXR and stress proteins in the common mussel Mytilus galloprovincialis. Aquat Toxicol 50: 167-176

Minier C, Moore MN (1996) Induction of multixenobiotic resistance in mussel blood cells. Marine Environ Res 42: 389-392

Money C, Braungardt C, Jha A, Worsfold P, Achterberg E (2011) Metal speciation and toxicity of Tamar Estuary water to larvae of the Pacific oyster, Crassostrea gigas. Marine Environmental Research $72 ; 3-12$

Moore MN, Icarus Allen J, McVeigh A (2006a) Environmental prognostics: an integrated model supporting lysosomal stress responses as predictive biomarkers of animal health status. Mar Environ Res 61: 278-304

Moore MN, Viarengo A, Donkin P, Hawkins JSA (2007) Autophagic and lysosomal reactions to stress in the hepatopancreas of blue mussels. Aqua Toxicol 84: 80-91

Mora P, Fournier D, Narbonne JF (1999) Cholinesterases from the marine mussels Mytilus galloprovincialis LmK. and Mytillus edulis from the freshwater bivalve Corbicula fluminea Muller. Comp Bioche Physiol C122: 353-361

Mora P, Michel X, Narbonne JF (1999) Cholinesterase activity as potential biomarker in two bivalves. Environ Toxicol Pharmacol 7: 253-260

Orban E, Di Lena G, Nevigato T, Casini I, Marzetti A, Caproni R (2002) Seasonal changes in meat content, condition index and chemical composition of mussels (Mytilus galloprovincialis) cultured in two different Italian sites. Food Chem 77: 57- 65 
Pan L, Ren J, Zheng D (2009) Effects of benzo(a)pyrene exposure on the antioxidant enzyme activity of scallop Chlamys farreri. Chin J Oceanol Limnol 27: 43-53

Pellerin-Massicotte J (1994) Oxidative processes as indicators of chemical stress in marine bivalves. J Aquat Ecosy Heal 3: 101-111

6

Pellerin-Massicotte J, (1997) Influence of elevated temperature and exposure on MDA levels and catalase activities in digestive glands of the blue mussel (Mytilus edulis L.). Journal de Recherche Océanographique 22: 91-98

Pfeifer S, D Schiedek, Dippner JW (2005) Effect of temperature and salinity on acetylcholinesterase activity, a common pollution biomarker, in Mytilus sp. from the south-western Baltic Sea. J Exp Mar Biol Ecol 320: 93-103

Regoli F (1992) Lysosomal responses as a sensitive stress index in biomonitoring heavy metal pollution. Mar Ecol Prog Ser 84: 63-69

Regoli F, Pellegrini D, Winston GW, Gorbi S, Giuliani S, Virno-Lamberti C, Bompadre S (2002) Application of biomarkers for assessing the biological impact of dredged materials in the Mediterranean: the relationship between antioxidant responses and susceptibility to oxidative stress in the red mullet (Mullus barbatus). Mar Pollu Bul 44: 912-922

Roméo M, Gnassia-Barelli M (1997) Effects of heavy metals on lipid peroxidation in the Mediterranean clam Ruditapes decussates. Comp Bioch Physiol 118: 33-37

Rougier C, Pourriot R, Lam-hoai T (2000) The genus Synchaeta in a north western Mediterranean coastal lagoon (Étang de Thau, France): taxonomical and ecological remarks. Hydrobio 436: 105-117

Sanchez W, Burgeot T, Porcher JM (2013) A novel "Integrated Biomarker Response" calculation based on reference deviation concept. Environ Sc Pol Res 20: 2721-2725

Serafim MA, Company RM, Bebianno MJ, Langston WJ (2002) Effect of temperature and size on metallothionein synthesis in the gill of Mytilus galloprovincialis exposed to cadmium. Mar Environ Res 54: 361-5

Serafim MA, Bebianno MJ (2001) Variation of metallothionein and metal concentrations in the digestive gland of the clam Ruditapes decussatus: sex and seasonal effects. Environ Toxicol Chem 20: $544-552$

Serafim A, Company R, Lopes B, Fonseca VF, Franc S, Vasconcelos RP, Bebianno MJ, Cabra HN (2012) Application of an integrated biomarker response index (IBR) to assess temporal variation of environmental quality in two Portuguese aquatic systems. Ecolo Indi 19: 215-225

Smital T, Sauerborn R, Pivcevic B, Krca S, Kurelec B (2000) Interspecies differences in Pglycoprotein mediated activity of multixenobiotic resistance mechanism in several marine and freshwater invertebrates. Comp Bioch Physiol C 126: 175-186

Snyder MJ (2000) Cytochrome P450 enzymes in aquatic invertebrate: recent advances and future directions. Aquat Toxicol 48: 529-547 
Sokolova IM (2004) Cadmium effects on mitochondrial function are enhanced by elevated temperatures in a marine poikilotherm, Crassostrea virginica Gmelin (Bivalvia: Ostreidae). J Exp Biol 207:2639-2648

Sureda A, Box A, Tejada S, Blanco A, Caixach J, Deudero S (2011) Biochemical responses of Mytilus galloprovincialis as biomarkers of acute environmental pollution caused by the Don Pedro oil spill (Eivissa Island, Spain). Aquat Toxicol 101: 540-549

Thain JE, Vethaak AD, Hylland K (2008) Contaminants in marine ecosystems: developing an integrated indicator framework using biological-effect techniques. ICES J Mar Sc 65:1508-1514

Trabelsi S, Driss M R, (2005) Polycyclic aromatic hydrocarbons in superficial coastal sediments from Bizerte lagoon, Tunisia. Mar Pollu Bul 50: 344-348

UNEP (1999) Manual of recommended biological techniques. Mediterranean action plan. Meeting of experts to review the MED POL Biomonitoring Programme. UNEP (OCA) / MED WG.132/6, United Nations Environment Programme, Athens, Greece

Viarengo A, Canesi L, Pertica M, Marcinelli G, Accomando R, Smaal AC, Orunesu M (1995) Stress on stress response: a simple monitoring tool in the assessment of a general stress sindrome in mussels. Mar Environ Res 39: 245-248.

Viarengo A, Lowe D, Bolognesi C, Fabbri E, Koehler A (2007) The use of biomarkers in biomonitoring: a 2-tier approach assessing the level of pollutantinduced stress syndrome in sentinel organisms. Compar Bioch and Physiol C 146: 281-300

Viarengo A, Nott J (1993) Mechanisms of heavy metal cation homeostasis in marine invertebrates. Compar Bioch and Physiol C 104: 355-372

Viarengo A, Ponzano E, Dondero F, Fabbri R (1997) A simple spectrophotometric method for metallothionein evaluation in marine organisms: an application to Mediterranean and Antartic molluscs. Mar Environ Res 44: 69- 84

Waldmann P, Pivcevic B, Mueller WEG, Zahn RK, Kurelec B (1995) Increased genotoxicity of acetylaminofluorene by modulators of multixenobiotic resistance mechanism: studies with the fresh water clam Corbicula fluminea. Mutat Res 342: 113-123

Zhang Z, Li X, Vandepeer M, Zhao W (2006) Effects of water temperature and air exposure on the lysosomal membrane stability of hemocytes in pacific oysters, Crassostrea gigas (Thunberg). Aquac 256: 502-509 


\section{Descriptions of Figures}

Figure 1: Map of the study area and location of sampling sites at the Bizerta Lagoon. Site 1: S1 Menzel Abdelrahmen, site 2: S2 Baie des Carrières.

Figure 2: Temporal and spatial variations in the condition index (A) and gonadic index (B) of M.galloprovincialis collected from the Menzel Abderahmen (Site 1) and Baie des Carrières (Site 2) in late spring and summer. Superscript "a" indicates $\rho<0.05$ (significantly different by ANOVA, multiple comparison and Duncan's test across sites $(n=30))$. Superscript "b" indicates $\rho<0.05$ (significantly different by ANOVA, multiple comparison and Duncan's test among month $(\mathrm{n}=30))$.

Figure 3: The Stress on stress response of mussels collected during summer 2011 from A. Menzel Abdelrahmen (Site 1) and B. Baie des Carrières (Site 2), both located in Bizerta Lagoon. . Superscript "a" indicates $\rho<0.05$ (significantly different by ANOVA, multiple comparison and Duncan's test across sites $(n=30))$. Superscript "b" indicates $\rho<0.05$ (significantly different by ANOVA, multiple comparison and Duncan's test among month $(n=30))$.

Figure 4: Spatial and temporal variations in biomarker response of Mytilus galloprovincialis collected from the Bizerta Lagoon, Menzel Abdelrahmen (Site 1) and Baie des Carrières (Site 2). A. Digestive gland BPH activity. B. Digestive gland GST activity. C. Densitometric analysis of MXR proteins as detected by Dot blot. D. Digestive gland metallothionein accumulation. E. Digestive gland MDA content. F. Digestive gland CAT activity. G. Gill AChE activity. Data represents means \pm SD. Superscript "a" indicates $\rho<0.05$ (significantly different by ANOVA, multiple comparison and Duncan's test across sites $(n=10))$. Superscript "b" indicates $\rho<0.05$ (significantly different by ANOVA, multiple comparison and Duncan's test among month $(\mathrm{n}=10))$.

Figure 5: Principal component analysis (PCA) based on mean values: chemical, biolochemical, biological and physic chemical water variables (PC 1 vs PC 2) in the mussel collected from the Bizerta Lagoon, a) Menzel Abderahmen (Site 1) and b) Baie des Carrières (Site 2)

Figure 6: Variations in water temperature and Integrated Biomarker Response calculated for a set of biomarkers measured in caged mussels sampled from two sites (Site 1 Menzel Abdelrahmen and Site 2 Baie des Carrières) at the Bizerta lagoon during the hot months. 


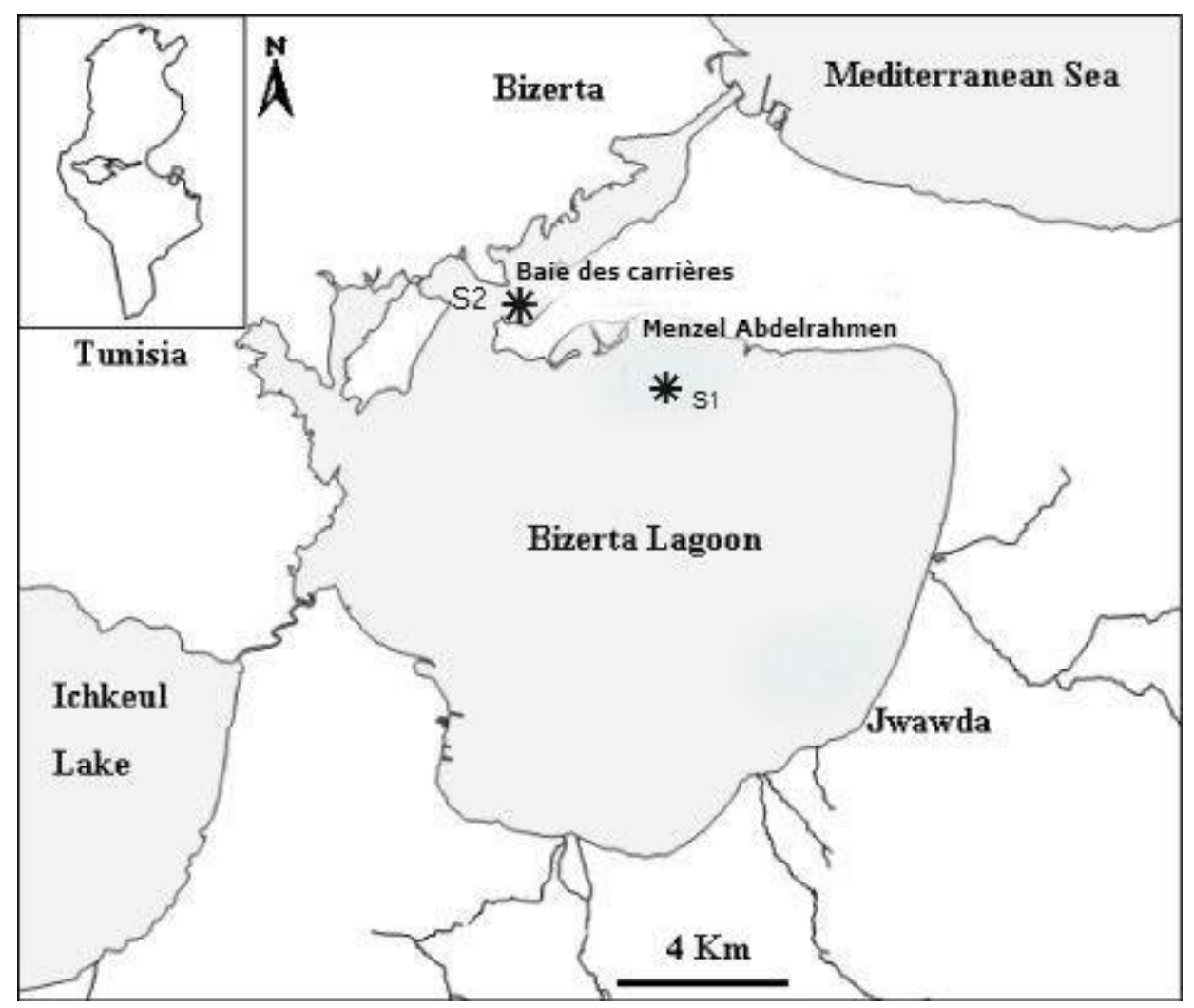



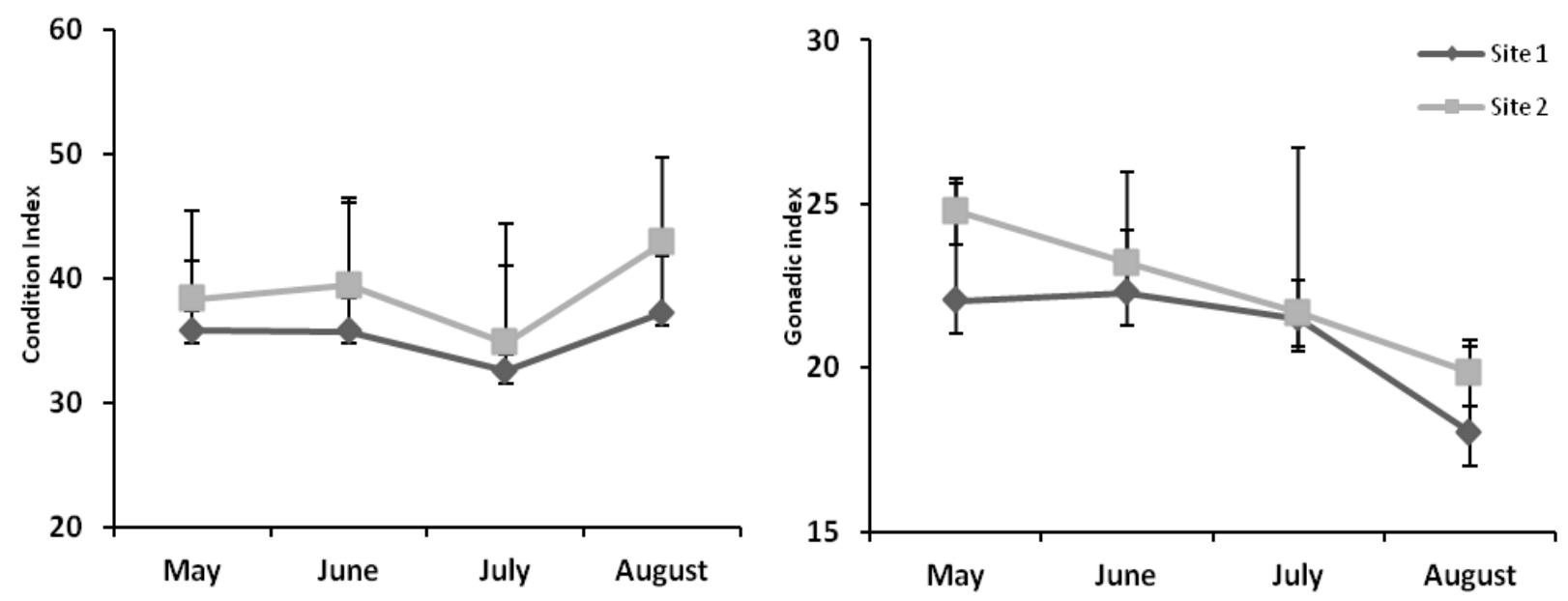


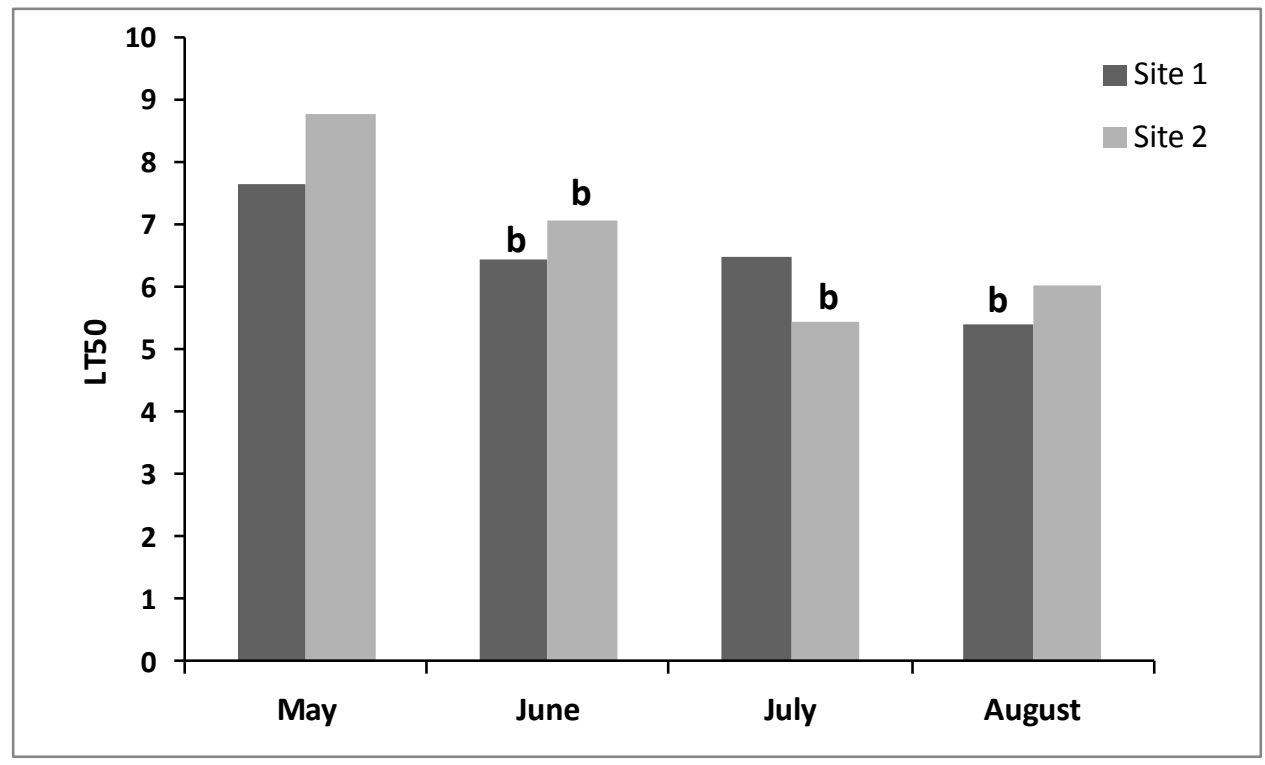



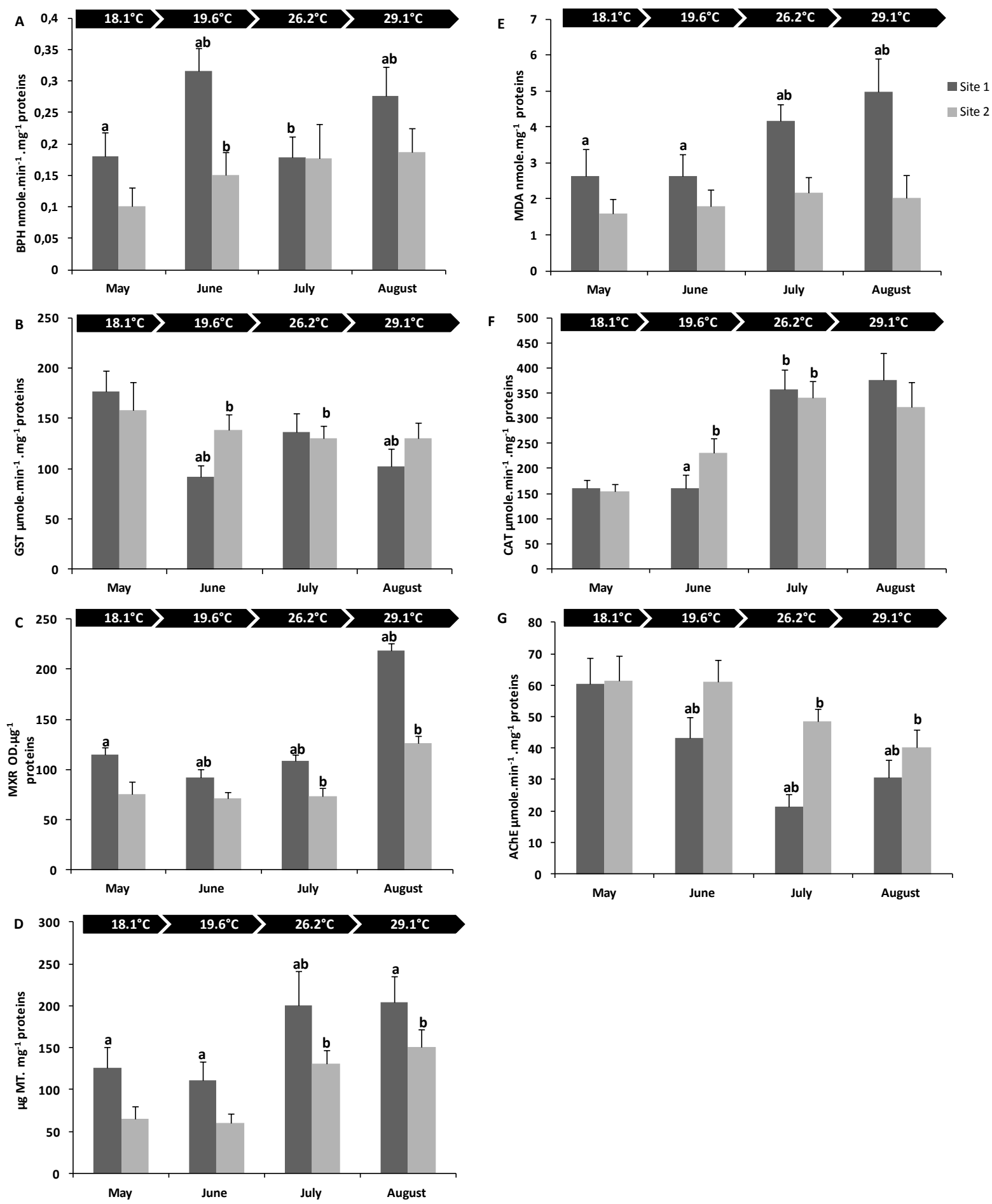


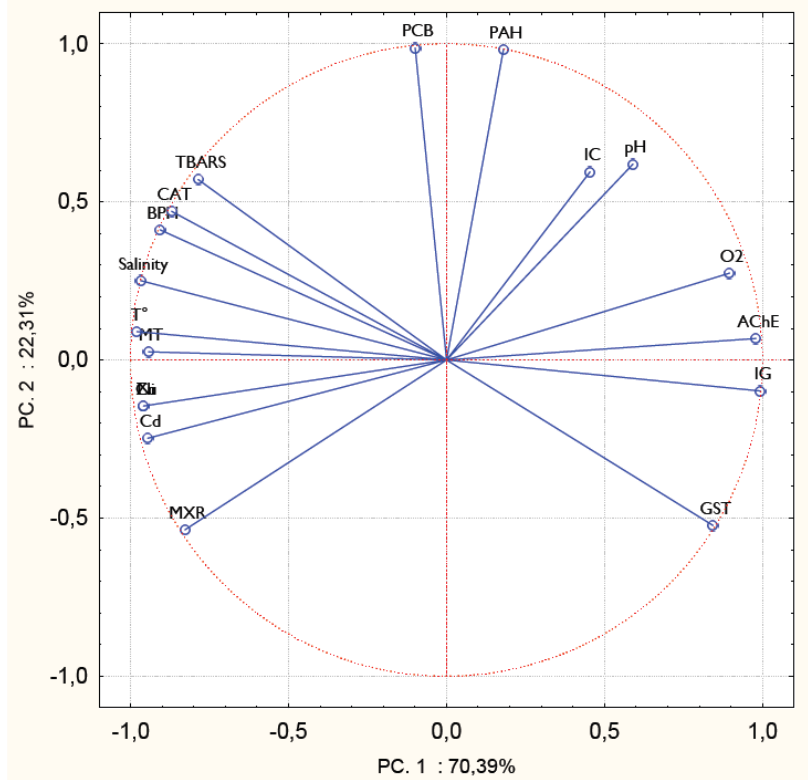

a

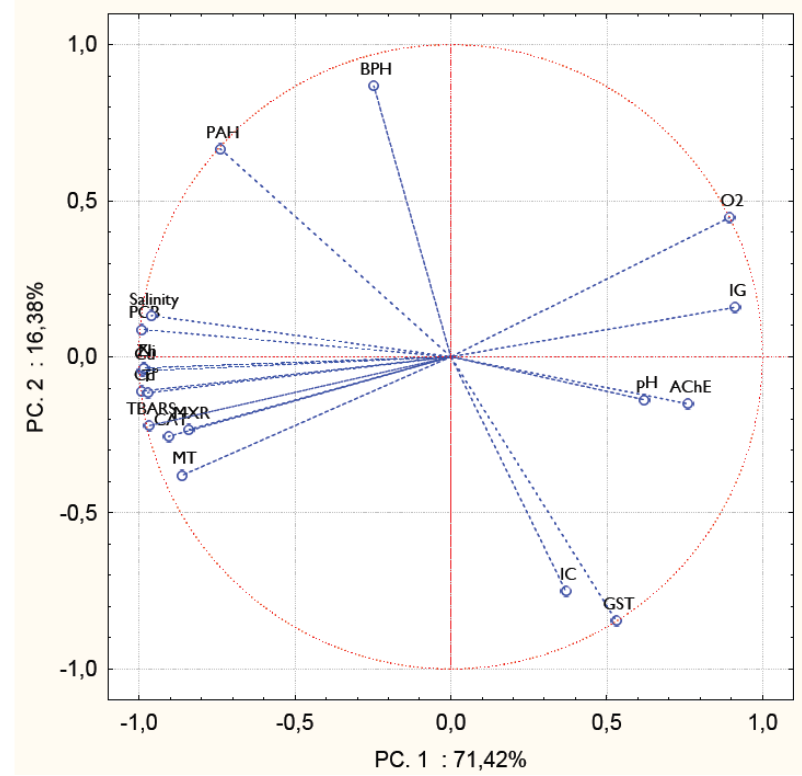

b 


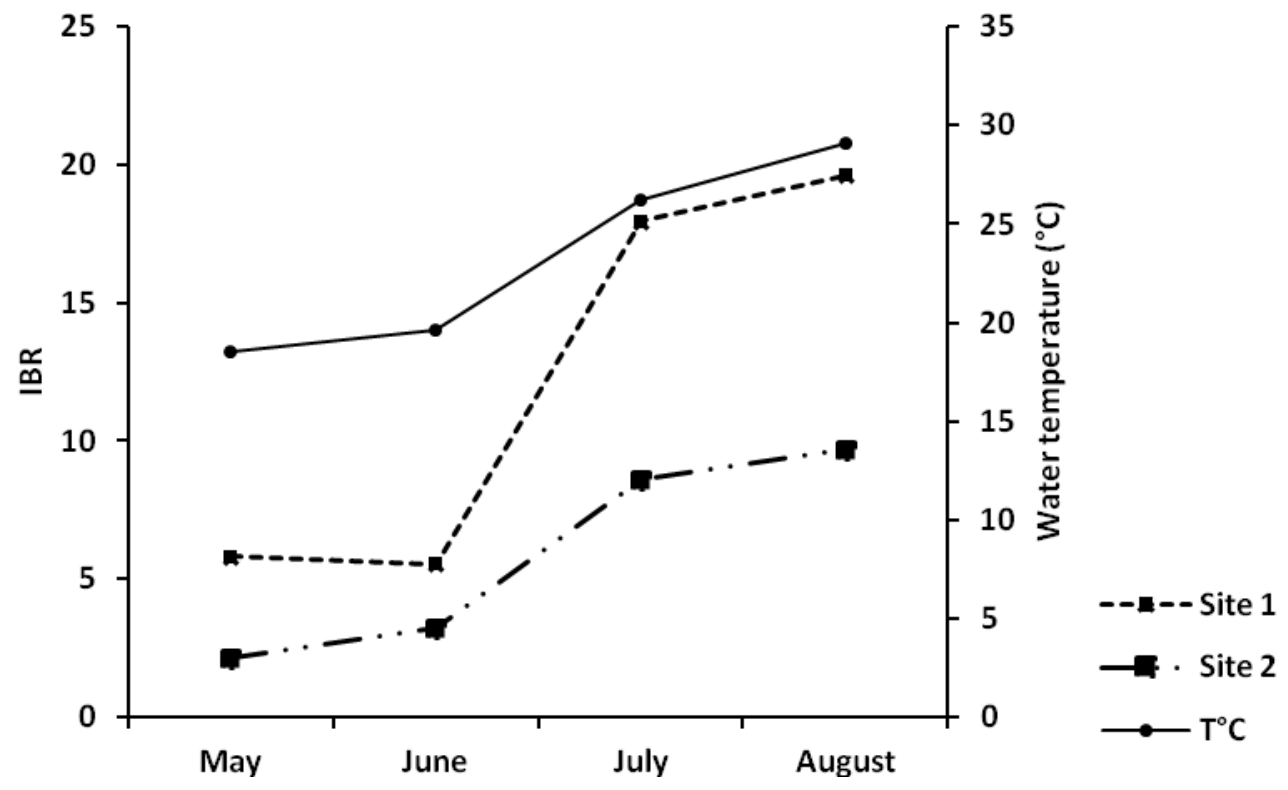




\section{Descriptions of Tables}

Table 1. Physical and Chemical parameters in Bizerta lagoon. Values represents the mean and the standard deviation of temperature ( $\mathrm{T}$ ), salinity (sal), $\mathrm{pH}$, dissolved oxygen (DO), turbidity (Tur), nitrite $\left(\mathrm{NO}_{2}^{-}\right)$, nitrate $\left(\mathrm{NO}_{3}{ }^{-}\right)$, ammonia $\left(\mathrm{NH}_{4}{ }^{+}\right)$, silicate $\left(\mathrm{SiO}_{3}{ }^{3-}\right)$ and phosphate $\left(\mathrm{PO}_{4}{ }^{3-}\right)$.

Table 2. PAH, PCB and trace metal concentrations in the digestive glands of M.galloprovincialis. The above values represent mean and standard deviation in pooled samples of digestive glands. Concentrations are expressed as $(\mu \mathrm{g} / \mathrm{g}$ dry weight), (ng/g dry weight) and ( $\mu \mathrm{g} / \mathrm{g}$ dry weight) respectively for PAHs, PCBs compounds and trace metals. $<$ DL: below detection limit. Superscript "a" indicates $\rho<0.05$ (significantly different by ANOVA, multiple comparison and Duncan's test across sites). Superscript "b" indicates $\rho<$ 0.05 (significantly different by ANOVA, multiple comparison and Duncan's test among month).

Table 3. Assessment of a set of biomarkers in M.galloprovincialis caged mussels at the Bizerta Lagoon. $\mathrm{BAC}=$ Background assessment criteria and $\mathrm{EAC}=$ Environmental assessment criteria.

a We cannot compare the EAC and BAC calculated in this study with those calculated for MT by Davies \&Vetaack 2012 because of the two different methods of analysis.

Table 4. Values of Integrated Biomarker Response for a set of biomarkers measured in caged mussels from two sites (Site 1 Menzel Abdelrahmen and Site 2 Baie des Carrières) at the Bizerta lagoon during the summer. 


\begin{tabular}{lcccc}
\hline & May & June & July & August \\
\hline $\mathrm{T}\left({ }^{\circ} \mathrm{C}\right)$ & $18.1 \pm 2.2$ & $19.6 \pm 2.1$ & $26.2 \pm 2.8$ & $29.1 \pm 3.1$ \\
$\mathrm{Sal}(\mathrm{psu})$ & $32 \pm 2.9$ & $32.7 \pm 3.4$ & $33.4 \pm 3.4$ & $37.8 \pm 2.9$ \\
$\mathrm{pH}$ & $8.35 \pm 1.2$ & $8.3 \pm 0.92$ & $8.5 \pm 0.81$ & $8 \pm 0.95$ \\
$\mathrm{DO}\left(\mathrm{mg} . \mathrm{L}^{-1}\right)$ & $7.5 \pm 0.6$ & $8 \pm 0.75$ & $6.9 \pm 0.58$ & $6.2 \pm 0.57$ \\
$\mathrm{Tur}(\mathrm{NTU})$ & $1.6 \pm 0.18$ & $1.8 \pm 0.95$ & $2.1 \pm 0.24$ & $2.5 \pm 0.18$ \\
$\mathrm{Chl}-\mathrm{a}\left(\mu \mathrm{g} . \mathrm{L}^{-1}\right)$ & $2.185 \pm 0.23$ & $2.012 \pm 0.21$ & $2.326 \pm 0.21$ & $3.642 \pm 0.29$ \\
$\mathrm{NO}_{2}^{-}\left(\mu \mathrm{mol} . \mathrm{L}^{-1}\right)$ & $0.57 \pm 0.05$ & $0.615 \pm 0.01$ & $0.535 \pm 0.06$ & $0.595 \pm 0.03$ \\
$\mathrm{NO}_{3}^{-}\left(\mu \mathrm{mol} . \mathrm{L}^{-1}\right)$ & $4.1 \pm 0.45$ & $4.3 \pm 0.44$ & $4.9 \pm 0.45$ & $5.6 \pm 0.6$ \\
$\mathrm{NH}_{4}^{+}\left(\mu \mathrm{mol} . \mathrm{L}^{-1}\right)$ & $23.65 \pm 2.42$ & $24 \pm 2.6$ & $21.7 \pm 2.19$ & $23.2 \pm 2.5$ \\
$\mathrm{SiO}_{3}{ }^{3-}\left(\mu \mathrm{mol} . \mathrm{L}^{-1}\right)$ & $3.385 \pm 0.37$ & $2.645 \pm 0.19$ & $3.125 \pm 0.33$ & $2.95 \pm 0.31$ \\
$\mathrm{PO}_{4}{ }^{3-}\left(\mu \mathrm{mol} . \mathrm{L}^{-1}\right)$ & $0.5 \pm 0.07$ & $0.715 \pm 0.06$ & $1.09 \pm 0.13$ & $1.3 \pm 0.17$ \\
\hline
\end{tabular}

Data represent the mean of five values measured in several sites on the lagoon at each sampling time. 


\begin{tabular}{|c|c|c|c|c|c|}
\hline Biomarkers & Tissue & $\begin{array}{c}\text { Suggested BAC } \\
\text { for the Bizerta } \\
\text { lagoon }\end{array}$ & $\begin{array}{c}\text { Suggested EAC } \\
\text { for the Bizerta } \\
\text { lagoon }\end{array}$ & $\begin{array}{c}\text { BAC OSPAR } \\
\text { (Davies et } \\
\text { Vetaack, 2012) }\end{array}$ & $\begin{array}{c}\text { EAC OSPAR } \\
\text { (Davies et } \\
\text { Vetaack, 2012) }\end{array}$ \\
\hline AChE & Gills & $\begin{array}{c}43 \\
\left(\mathrm{nmol} \cdot \mathrm{mn}^{-1} \cdot \mathrm{mg}^{-1} \mathrm{P}\right)\end{array}$ & $\begin{array}{c}30 \\
\left(\mathrm{nmol} \cdot \mathrm{mn}^{-1} \cdot \mathrm{mg}^{-1} \mathrm{P}\right)\end{array}$ & $\begin{array}{c}15 \\
\left(\mathrm{nmol} \cdot \mathrm{mn}^{-1} \cdot \mathrm{mg}^{-1} \mathrm{P}\right)\end{array}$ & $\begin{array}{c}10 \\
\left(\mathrm{nmol} \cdot \mathrm{mn}^{-1} \cdot \mathrm{mg}^{-1} \mathrm{P}\right)\end{array}$ \\
\hline $\begin{array}{c}\underset{\left(\mu \mathrm{mol} \cdot \mathrm{mn}^{-1} \cdot \mathrm{mg}^{-1}\right.}{\text { CA }} \\
\mathrm{P})\end{array}$ & Digestive gland & 335 & 370 & - & - \\
\hline $\begin{array}{c}\text { MDA } \\
(\text { nmol.mg } \\
-1\end{array}$ & Digestive gland & 2 & 5 & - & - \\
\hline $\begin{array}{c}\mathbf{M T}^{\mathbf{a}} \\
\left(\mu \mathrm{g} \cdot \mathrm{mg}^{-1} \mathrm{P}\right)\end{array}$ & Digestive gland & 144 & 203 & & \\
\hline $\begin{array}{l}\text { BPH (nmol.mn } \\
\left.{ }^{1} . \mathrm{mg}^{-1} \mathrm{P}\right)\end{array}$ & Digestive gland & 0.2 & 0.3 & - & - \\
\hline $\begin{array}{c}\text { GST } \\
\left(\mu \mathrm{mol}_{\mathrm{mn}}^{-1} \cdot \mathrm{mg}\right. \\
\mathrm{P})\end{array}$ & Digestive gland & 152 & 165 & - & - \\
\hline $\begin{array}{c}\text { MXR } \\
\left(\mathrm{OD} \cdot \mu \mathrm{g}^{-1} \mathrm{P}\right)\end{array}$ & Gills & 111 & 187 & - & - \\
\hline
\end{tabular}




\begin{tabular}{|c|c|c|c|c|c|c|c|c|}
\hline \multirow[t]{2}{*}{ Compound } & \multicolumn{4}{|c|}{ Site 1 (Menzhel Abderahmen) } & \multicolumn{4}{|c|}{ Site 2 (Baie des Carrières) } \\
\hline & May & June & July & August & May & June & July & August \\
\hline Acenaphtylene & $<\mathrm{DL}$ & $<\mathrm{DL}$ & $<\mathrm{DL}$ & $<\mathrm{DL}$ & $<\mathrm{DL}$ & $<\mathrm{DL}$ & $<\mathrm{DL}$ & $<\mathrm{DL}$ \\
\hline Acenaphtene & $<\mathrm{DL}$ & $<\mathrm{DL}$ & $<\mathrm{DL}$ & $<\mathrm{DL}$ & $<\mathrm{DL}$ & $<\mathrm{DL}$ & $<\mathrm{DL}$ & $<\mathrm{DL}$ \\
\hline Naphthalene & $0,1 \pm 0.01$ & $0,15 \pm 0.04$ & $0,15 \pm 0.02$ & $0,16 \pm 0.03$ & $<\mathrm{DL}$ & $0,06 \pm 0.01$ & $0,07 \pm 0.01^{\mathrm{a}}$ & $0,08 \pm 0.01^{\mathrm{a}}$ \\
\hline Phenanthrene & $0,11 \pm 0.01$ & $0,12 \pm 0.01$ & $0,17 \pm 0.04$ & $0,14 \pm 0.03$ & $<\mathrm{DL}$ & $0,08 \pm 0.01$ & $0,07 \pm 0.01^{\mathrm{a}}$ & $0,06 \pm 0.01^{\mathrm{a}}$ \\
\hline Anthracene & $<\mathrm{DL}$ & $<\mathrm{DL}$ & $<\mathrm{DL}$ & $<\mathrm{DL}$ & $<\mathrm{DL}$ & $<\mathrm{DL}$ & $<\mathrm{DL}$ & $<\mathrm{DL}$ \\
\hline Fluoranthene & $0,19 \pm 0.03$ & $0,22 \pm 0.04$ & $0,25 \pm 0.04$ & $0,2 \pm 0.04$ & $0,18 \pm 0.05$ & $0,17 \pm 0.02$ & $0,16 \pm 0.02^{\mathrm{a}}$ & $0,11 \pm 0.02^{\mathrm{a}}$ \\
\hline Pyrene & $0,22 \pm 0.04$ & $0,21 \pm 0.05$ & $0,2 \pm 0.04$ & $0,21 \pm 0.04$ & $0,15 \pm 0.04$ & $0,15 \pm 0.03$ & $0,15 \pm 0.02$ & $0,1 \pm 0.01^{\mathrm{a}}$ \\
\hline Benzo(a)anthracene & $0,25 \pm 0.04$ & $0,24 \pm 0.04$ & $0,19 \pm 0.04$ & $0,28 \pm 0.06$ & $0,19 \pm 0.04$ & $0,14 \pm 0.03^{\mathrm{a}}$ & $0,15 \pm 0.03$ & $0,12 \pm 0.02^{\mathrm{a}}$ \\
\hline Chrysene & $0,11 \pm 0.02$ & $0,15 \pm 0.02$ & $0,14 \pm 0.02$ & $0,16 \pm 0.02$ & $<\mathrm{DL}$ & $<\mathrm{DL}$ & $<\mathrm{DL}$ & $<\mathrm{DL}$ \\
\hline Benzo(b)fluoranthene & $0,14 \pm 0.01$ & $0,19 \pm 0.03$ & $0,17 \pm 0.03$ & $0,19 \pm 0.04$ & $<\mathrm{DL}$ & $<\mathrm{DL}$ & $<\mathrm{DL}$ & $<\mathrm{DL}$ \\
\hline Benzo(e)Pyrene & $0,09 \pm 0.01$ & $0,12 \pm 0.01$ & $0,12 \pm 0.02$ & $0,13 \pm 0.01$ & $0,06 \pm 0.01$ & $0,06 \pm 0.01^{\mathrm{a}}$ & $0,08 \pm 0.01$ & $0,09 \pm 0.01$ \\
\hline Benzo(a)Pyrene & $0,22 \pm 0.03$ & $0,3 \pm 0.07$ & $0,28 \pm 0.05$ & $0,31 \pm 0.05$ & $0,08 \pm 0.01^{\mathrm{a}}$ & $0,1 \pm 0.01^{\mathrm{a}}$ & $0,09 \pm 0.01^{\mathrm{a}}$ & $0,09 \pm 0.01^{\mathrm{a}}$ \\
\hline Benzo(g,h,i)Perylene & $0,2 \pm 0.04$ & $0,28 \pm 0.07$ & $0,25 \pm 0.04$ & $0,25 \pm 0.03$ & $<\mathrm{DL}$ & $<\mathrm{DL}$ & $<\mathrm{DL}$ & $<\mathrm{DL}$ \\
\hline Dibenzo[a,h]anthracene & $<\mathrm{DL}$ & $<\mathrm{DL}$ & $<\mathrm{DL}$ & $<\mathrm{DL}$ & $<\mathrm{DL}$ & $<\mathrm{DL}$ & $<\mathrm{DL}$ & $<\mathrm{DL}$ \\
\hline PCB-18 & $0.44 \pm 0.04$ & $0.48 \pm 0.06$ & $0.53 \pm 0.04$ & $0.28 \pm 0.03$ & $0.23 \pm 0.04^{\mathrm{a}}$ & $0.27 \pm 0.04 a$ & $0.26 \pm 0.04$ & $0.20 \pm 0.02$ \\
\hline PCB-28+31 & $<\mathrm{DL}$ & $<\mathrm{DL}$ & $<\mathrm{DL}$ & $<\mathrm{DL}$ & $<\mathrm{DL}$ & $<\mathrm{DL}$ & $<\mathrm{DL}$ & $<\mathrm{DL}$ \\
\hline PCB-52 & $1.44 \pm 0.14$ & $1.60 \pm 0.20$ & $1.79 \pm 0.19$ & $0.93 \pm 0.11$ & $0.78 \pm 0.12^{\mathrm{a}}$ & $0.90 \pm 0.15^{\mathrm{a}}$ & $0.88 \pm 0.12^{\mathrm{a}}$ & $0.66 \pm 0.06^{\mathrm{a}}$ \\
\hline PCB-44 & $1.68 \pm 0.16$ & $1.11 \pm 0.14$ & $1.24 \pm 0.13$ & $0.64 \pm 0.07$ & $0.54 \pm 0.08^{\mathrm{a}}$ & $0.62 \pm 0.10^{\mathrm{a}}$ & $0.61 \pm 0.08^{\mathrm{a}}$ & $0.47 \pm 0.05^{\mathrm{a}}$ \\
\hline PCB-101 & $9.54 \pm 0.92$ & $10.57 \pm 1.33$ & $11.80 \pm 1.25$ & $9.94 \pm 1.15$ & $5.15 \pm 0.80^{a}$ & $5.92 \pm 0.98^{\mathrm{a}}$ & $5.84 \pm 0.79^{a}$ & $4.51 \pm 0.43^{\mathrm{a}}$ \\
\hline PCB-118 & $8.72 \pm 0.84$ & $9.71 \pm 1.22$ & $8.52 \pm 0.90$ & $9.44 \pm 1.10$ & $4.73 \pm 0.74^{a}$ & $5.44 \pm 0.90^{\mathrm{a}}$ & $5.36 \pm 0.73^{a}$ & $4.14 \pm 0.40^{\mathrm{a}}$ \\
\hline PCB-149 & $3.71 \pm 0.36$ & $4.13 \pm 0.52$ & $4.61 \pm 0.49$ & $8.52 \pm 0.99$ & $2.01 \pm 0.31^{\mathrm{a}}$ & $2.31 \pm 0.38^{\mathrm{a}}$ & $2.28 \pm 0.31^{\mathrm{a}}$ & $1.76 \pm 0.17^{\mathrm{a}}$ \\
\hline PCB-138 & $9.80 \pm 0.94$ & $10.91 \pm 1.37$ & $12.17 \pm 1.29$ & $13.97 \pm 1.62$ & $5.31 \pm 0.83^{\mathrm{a}}$ & $6.11 \pm 1.01^{\mathrm{a}}$ & $6.02 \pm 0.82^{\mathrm{a}}$ & $4.65 \pm 0.45^{a}$ \\
\hline PCB-153 & $16.98 \pm 1.63$ & $18.12 \pm 2.28$ & $16.39 \pm 1.74$ & $20.09 \pm 2.33$ & $14.01 \pm 2.19$ & $19.38 \pm 3.22$ & $18.30 \pm 2.49$ & $13.63 \pm 1.31^{\mathrm{a}}$ \\
\hline PCB-180 & $21.59 \pm 2.07$ & $18.92 \pm 2.38$ & $17.26 \pm 1.83$ & $16.30 \pm 1.89$ & $9.22 \pm 1.44^{\mathrm{a}}$ & $10.60 \pm 1.76^{\mathrm{a}}$ & $10.45 \pm 1.42^{\mathrm{a}}$ & $10.24 \pm 0.98^{\mathrm{a}}$ \\
\hline PCB-194 & $2.56 \pm 0.25$ & $2.23 \pm 0.28$ & $2.48 \pm 0.26$ & $2.05 \pm 0.24$ & $1.08 \pm 0.17^{\mathrm{a}}$ & $1.25 \pm 0.21$ & $1.23 \pm 0.17^{\mathrm{a}}$ & $0.95 \pm 0.09^{\mathrm{a}}$ \\
\hline $\mathrm{Cd}$ & $0.34 \pm 0.06$ & $0.36 \pm 0.07$ & $0.43 \pm 0.06$ & $0.49 \pm 0.09$ & $0.18 \pm 0.02^{\mathrm{a}}$ & $0.19 \pm 0.03^{\mathrm{a}}$ & $0.19 \pm 0.04^{\mathrm{a}}$ & $0.24 \pm 0.04^{\mathrm{a}}$ \\
\hline $\mathrm{Cu}$ & $2.53 \pm 0.11$ & $2.68 \pm 0.11$ & $3.01 \pm 0.19$ & $3.70 \pm 0.15$ & $1.72 \pm 0.10^{\mathrm{a}}$ & $1.91 \pm 0.11^{\mathrm{a}}$ & $1.96 \pm 0.12^{\mathrm{a}}$ & $2.39 \pm 0.14^{\mathrm{a}}$ \\
\hline $\mathrm{Zn}$ & $36.90 \pm 1.95$ & $39.11 \pm 2.07$ & $43.17 \pm 2.28$ & $53.96 \pm 2.85$ & $22.84 \pm 1.40^{\mathrm{a}}$ & $25.35 \pm 1.55^{\mathrm{a}}$ & $26.04 \pm 1.60^{\mathrm{a}}$ & $31.77 \pm 1.95^{\mathrm{a}}$ \\
\hline $\mathrm{Ni}$ & $2.84 \pm 0.23$ & $3.01 \pm 0.25$ & $3.33 \pm 0.27$ & $4.16 \pm 0.34$ & $1.68 \pm 0.16^{\mathrm{a}}$ & $1.87 \pm 0.18^{\mathrm{a}}$ & $1.92 \pm 0.19^{\mathrm{a}}$ & $2.34 \pm 0.23^{\mathrm{a}}$ \\
\hline
\end{tabular}

\begin{tabular}{lcc}
\hline & IBR Site 1 & IBR Site 2 \\
\hline May & 5,80 & 2,13 \\
June & 5,54 & 3,22 \\
July & 17,94 & 8,57 \\
August & 19,63 & 9,67 \\
\hline
\end{tabular}





\section{Dear Editor,}

Thank you very much for you message concerning the review of our manuscript titled "Effects of increasing temperatures on biomarker responses and accumulation of hazardous substances in rope mussels (Mytilus galloprovincialis) from the Bizerta Lagoon”. ESPR-D-13-01857. Authors also want to thank the advisors for their instructive comments and for the interest showed regarding our manuscript.

Answer to the Reviewer comments:

\section{$\underline{\text { Reviewer \#1: }}$}

\section{Specific comments:}

1. Page 3, line 82: please indicate the full name before the abreviation PBDEs. Done

2. Line 84: this is a continuation of the previous text, so paragraph should not be used here.

Response: this sentence is a connection between two paragraphs. We have reformulated this passage.

3. Line 97: "oxidative stress" and not "oxidative stresses; and delete "the" before Mytilus. Done

4. Line 98: delete "mussel" Done

5. Line 99: "benzo..." and not "Benzo..."; please notice that the name of the chemicals should not be started by caps logs unless it starts a sentence; please review all the text regarding this, there are similar mistakes in other points of the text. Done

6. Page 4, lines 114-115: What kind of index are you referring too? This should be clearly indicated.

Response

The condition index is mainly used for two purposes: first, as a gauge of the quality of meat for the market place (Orban et al., 2002), and second, an ecophysiological measure of the health status of animals. Indeed, it summarizes the physiological activity of the organisms (growth, reproduction, secretion, etc.) under given environmental conditions (Lucas and Beninger, 1985).

The reference used for calculating CI was added in materials and methods section.

7. Line 143: what kind of trace elements? Metals? This should be indicated.

Response: The sentence was reformulated as: 
Tissue levels of metallothionein proteins (MT) were estimated in mussel digestive glands in order to assess the trace metals pollution in aquatic environment end evaluate their biological effects on sentinel organisms.

8. Lines 161-162: the sentence should be supported by a reference.

Response: The following reference was added in line 162 and to the final reference list.

Mediterranean Action Plan (2011) Development of assessment criteria for hazardous substances in the Mediterranean. UNEP (DEPI)/MED WG. 365/Inf.8

9. The objectives of the work and the rationale should be clearly indicated at the end of the discussion. Please notice that applying an index is not by itself a scientific objective and that no ecological risk assessment was performed. So, the central and specific objectives are not indicated in a suitable way.

Response

The objectives of the work were restate at the end of the introduction, as requested by the reviewer: L165 "The aim of this study was to examine the influence of increasing temperatures in spring and summer on the biomarker responses of mussels inhabiting a North African lagoon, recognized as a sensitive area in terms of temperature changes and pollution. Biomarker variations were initially compared during the highest temperature elevation, between spring and summer. The amplitude response of the biomarkers was then studied across two sites characterized by different levels of chemical contamination"

Application of composite indices is not a goal in itself, but this is the first work that applies these methods in this lagoon.

10. page 5, Material and Methods: why was this particular lagoon selected?

Response

This environment, in light of its location between Lake Ichkeul and the Mediterranean, is characterized, as are most Mediterranean lagoons, by a great variability in its ambient conditions, in particular insofar as the hydrological parameters, such as salinity, temperature and dissolved oxygen levels, are concerned.

11. Why only 2 sampling sites and why these particular ones?

Response

The aim of studding only 2 sampling sites was not to compare the contamination levels but to evaluate the physiological responses of M.galloprovincialis in the lagoon. 
12. What about reference sites in another system that could be used as reference? As far as I could understand both sampling sites are contaminated, so how can the effects on mussels can be correctly evaluated?

\section{Response}

Selecting a reference site outside the lagoon does not appear relevant because we wanted to meet the homogeneity Exposure of the molds within the lagoon. This is a constraint of the study we had to integrate. A site at sea open would not have to compare homogeneous exposure areas between lagoon and open sea views. We have selected two sites different contamination with uncontaminated site and a site more contaminated. The difference in response biomarkers shows that the choice of the two sites is sufficient contrast in contamination chemical.

13. Why the sampling was made only in spring and summer? Why not also in the Autumn and Winter to also investigate seasonal variability? Notice that in summer mussels may be affected by the bivalve summer syndrome, especially in very warm summers, while in the spring they are actively reproducing what may introduce bias on the biomarkers results.

\section{Response}

The present work constitutes a continuation of previous investigation conducted by our group using the same organism (Banni et al.2011 and Kamel et al. 2012) in these works we establish the physiological response of the mussel during an annual cycle in the Bizerta lagoon, these results showed a very important variation in physiological response due to thermal variation in summer, we have also study the effects of increasing temperature in experimental condition (in laboratory).

14. The size of the mussels should be indicated and the size of mussels from the two sampling sites should be compared with an adequate statistical analysis (e.g. Students ttest). Done

\section{Response:}

Line 180 : Mussels of similar sizes (5-7 cm shell length) were sampled monthly from both sites in late spring and summer 2011.

Line 332; Differences in mussel size between the two sites were evaluated using Student test ( $\rho$ $<0.05$ ) for each sampling date

15. Where standards used in chemical analysis determinations? This should be cleraly indicate, as well their type and the values obtained for validatio purposes.Line 238: what do you mean exactly by "when did not recover...". How was recover!y assessed?

\section{Response}

Standards were added in Line 206. 
L 238: here recover it mean to go back. The term was replaced with "react"

16. Line 45: check the date of the reference Bradford, it appears here as 1979, in other sites as 1976 that I believe is the date you would like to indicate. Check also the name of the reagent in line 246 . Done

\section{Response:}

it was a not careful mistake, the correct reference is Bradford 1976, this has been corrected in the text and in the reference list

16. All the description of biomarkers determination detechniques lack important details, please complete it carefully, indicate the equipment (model company) used, the temperature, some references are missing, etc. Done

Response:

All the section $M \& M$ has been verified, and the authors have added more details and reviewer recommendations were taken into account.

16. How many replicates where done? Individual animals or pooled samples? this should be clearly indicated for both chemical and biological analysis.

\section{Response}

Biological analysis : Ten mussels $(\mathrm{n}=10)$ from each site were analyzed individually for each biomarker measurements.

Chemical analysis : PAH content in the digestive gland fractions (three distinct pools prepared (pool $=3$ digestives glands))

Determination of PCB content Freeze-dried digestive gland tissue (10 g)

Determination of heavy metal content: (five distinct pools prepared as described above)

17. The use of the Analysis of variance (ANOVA) is only adequate when ANOVA assumptions are fulfield. How were they tested (for each parameter) and if data transformations were made they should be indicated.

\section{Response}

The experimental data were first tested for normality and homogeneity of variance to meet statistical demands. Data was expressed as mean \pm standard deviation (SD).

18. What kind of ANOVA was done with what data precisely? this should be clear. 
Response: Data statistical analysis was performed using using one-way analysis of variance (ANOVA) and Duncan's test for multiple range comparison $(\rho<0.05)$ was considered as significant. This was added in the Ms, statistics sub-section (line: 323 -328 )

19. Why was the Duncan test selected and not the Tukey (or other multicomparison test?)

Response

We applied the Duncan test because it's a multiple comparison procedure for comparing all means. This is a step by step procedure, based on a Studentized distribution ranks. This procedure indicates which means are significantly different from each other.

20. What do you mean by "Pearson correlation matrix"? Are you referring to the Pearson correlation coefficient? If so, are the data appropriate for its use? This should be checked. Anyway I found difficult to consider correlation because at least some of the biomarkers are expected to have a kind of bell shape distribution.

\section{Response}

The term "Pearson correlation matrix" was adjusted as suggested by reviewer. Authors totally agree with the reviewer comment regarding the rational in using the Pearson correlation coefficient. However, only significant correlations were reported in the text.

\section{RESULTS}

21. Table 1, correspond text in page 10 and legend of the table: What are exactly the values shown in the table? Pontual measurements? Means? If they are punctual measurements/determinations with replicates, they have no meaning. If they are means, the number of true replicates and how and when the measurements/determinations were made should be indicated. Where they done at low time or high tide? at What time of the day, etc? Variability (e.g. SD) should be given. This should be indicated in the material and methods section and in the table legend.

\section{Response}

Water quality was assessed at each sampling time. The physico-chemical quality of the Bizerta Lagoon waters was monitored in situ. Salinity $(\mathrm{g} / \mathrm{L})$, temperature $\left({ }^{\circ} \mathrm{C}\right)$, dissolved oxygen $(\mathrm{mg} / \mathrm{L})$, and $\mathrm{pH}$ were measured at the sampling sites with a Multi 350i Multimeter.

Values represents the mean and the standard deviation of temperature (T), salinity (sal), $\mathrm{pH}$, dissolved oxygen (DO), turbidity (Tur), nitrite $\left(\mathrm{NO}_{2}{ }^{-}\right)$, nitrate $\left(\mathrm{NO}_{3}{ }^{-}\right)$, ammonia $\left(\mathrm{NH}_{4}{ }^{+}\right)$, silicate $\left(\mathrm{SiO}_{3}{ }^{3-}\right)$ and phosphate $\left(\mathrm{PO}_{4}{ }^{3-}\right)$. 
Data represent the mean of five values measured in several sites on the lagoon at each sampling time.

22. The corresponding text in page 10 should be discussed after statistical analysis.

\section{Response}

We took into account the reviewer comments

Trace metal concentrations in the digestive glands of mussel showed both temporal and spatial variations. In general, the levels of all metals $(\mathrm{Cd}, \mathrm{Cu}, \mathrm{Zn}$ and $\mathrm{Ni}$ ) were significantly higher in the digestive glands of mussels sampled from Site 1 versus Site $2(\rho<0.05)$.

Almost all polycyclic aromatic hydrocarbon (PAH) compounds measured in mussel digestive glands were three times higher in those of mussels from the Menzel Abderahmen site (Site 1) versus the Baie des Carrières site (Site 2), the PAH content were significantly higher in digestive gland of mussel collected from Site 1 then Site $2(\rho<0.05) \ldots$

Concentrations of polychlorinated biphenyls (PCBs) in digestive glands were significantly higher in mussels from Site 1 versus Site $2(\rho<0.05)$. The monthly trends of $\Sigma$ PCB at both sites were similar, with an increase in levels from May to August.

23. Chemical analysis Where there statistical significant differences between the sites for each determination?

\section{Response}

The statistical test was specified in the materials and methods section and the following was added to the table 2 description

a: Statistically significant differences $(\mathrm{P}<0.05)$ in comparison with site 1 at the same sampling period

24. The corresponding text in page 10 should be written according the results of statistical analysis.

This was adjusted in the point 21.

25. A table with the full results of statistical analysis of biological parameters should be given. The $\mathrm{F}$ values, degrees of fredoom should be given in addition to $\mathrm{P}$ values. The results section (page 11 and 12) should be written based on the results of statistical analysis.

Response 
$\mathrm{P}$ and $\mathrm{F}$ values were added in results section, and a file containing manufacturing all statistical analyzes was joined.

26. I suggest to use a multivariate analysis approach integrating biological responses, physico-chemical parameters and chemical analysis (e.g. redundancy analysis) in order to relate biological responses and factors contributing to them.

Response

Reviewer recommendations were taken into account, ACP integrating biological responses, physico-chemical parameters and chemical analysis was performed with Statistica 6 and included in the manuscript at Figure 5

27. IBR values should be indicated in a table.

Table 4: Values of Integrated Biomarker Response for a set of biomarkers measured in caged mussels from two sites (Site 1 Menzel Abderahmen and Site 2 Baie des Carrières) at the Bizerta lagoon during the summer.

\begin{tabular}{lrr}
\hline & IBR Site 1 & IBR Site 2 \\
\hline May & 5,80 & 2,13 \\
June & 5,54 & 3,22 \\
July & 17,94 & 8,57 \\
August & 19,63 & 9,67 \\
\hline
\end{tabular}

\section{Response}

28. The figure 3 has no variability, this should be shown. Againg the sites should be compared by statistical analysis, as for the other biomarkers (for example first with a two way ANOVA with interactions with sites and time as main factors, and then relevant parameters should be integrated using a RDA analyis.

\section{Response}

This figure was adjusted and we applied ANOVA and Duncan's test.

29. The legend of the figures should be improved as indicated for tables, among other corrections. Done

30 .

31. Correlations based on the Pearson correlation coeficient are not adequate because some of the parameters may have a bell shap or sigmoidal distribution.

\section{Response}

Authors totally agree with the reviewer comment regarding the rational in using the Pearson correlation coefficient. However, only significant correlations were reported in the text. Authors want also to highlight the fact that other statics analysis were tested "PCA" and thus authors are in agreement with the observation of reviewer and added an 
32. The discussion, conclusions and the abstract should be reformulated after the adequate analysis of data.

\section{Response}

The manuscript was reviewed by the authors, it has added more details in the materials and methods section, the results were discussed according to the statistical analysis. 
Supplementary Material
Click here to download Supplementary Material: statistical analysis.docx

Supplementary Material
Click here to download Supplementary Material: statistical analysis.docx

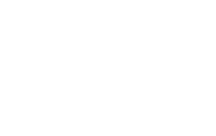

.

-

.

列

t

$\sqrt{2}$

(1)

(1) (1) (1) (1) (1)

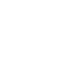

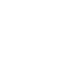

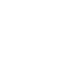

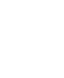
.

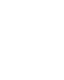

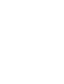

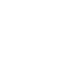

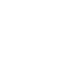
. 